University of Nebraska - Lincoln

DigitalCommons@University of Nebraska - Lincoln

2008

\title{
Application of Spectral Remote Sensing for Agronomic Decisions
}

\author{
J. L. Hatfield \\ United States Department of Agriculture, Agricultural Research Service, jerry.hatfield@ars.usda.gov \\ Anatoly A. Gitelson \\ University of Nebraska - Lincoln, agitelson2@unl.edu \\ James S. Schepers \\ United States Department of Agriculture, Agricultural Research Service, james.schepers@gmail.com \\ C. L. Walthall \\ United States Department of Agriculture, Agricultural Research Service
}

Follow this and additional works at: https://digitalcommons.unl.edu/natrespapers

Part of the Natural Resources and Conservation Commons

Hatfield, J. L.; Gitelson, Anatoly A.; Schepers, James S.; and Walthall, C. L., "Application of Spectral Remote Sensing for Agronomic Decisions" (2008). Papers in Natural Resources. 257.

https://digitalcommons.unl.edu/natrespapers/257

This Article is brought to you for free and open access by the Natural Resources, School of at DigitalCommons@University of Nebraska - Lincoln. It has been accepted for inclusion in Papers in Natural Resources by an authorized administrator of DigitalCommons@University of Nebraska - Lincoln. 


\title{
Application of Spectral Remote Sensing for Agronomic Decisions
}

\author{
J. L. Hatfield,* A. A. Gitelson, J. S. Schepers, and C. L. Walthall
}

This article is a U.S. government work, and is not subject to copyright in the United States.

\section{ABSTRACT}

Remote sensing has provided valuable insights into agronomic management over the past $40 \mathrm{yr}$. The contributions of individuals to remote sensing methods have lead to understanding of how leaf reflectance and leaf emittance changes in response to leaf thickness, species, canopy shape, leaf age, nutrient status, and water status. Leaf chlorophyll and the preferential absorption at different wavelengths provides the basis for utilizing reflectance with either broad-band radiometers typical of current satellite platforms or hyperspectral sensors that measure reflectance at narrow wavebands. Understanding of leaf reflectance has lead to various vegetative indices for crop canopies to quantify various agronomic parameters, e.g., leaf area, crop cover, biomass, crop type, nutrient status, and yield. Emittance from crop canopies is a measure of leaf temperature and infrared thermometers have fostered crop stress indices currently used to quantify water requirements. These tools are being developed as we learn how to use the information provided in reflectance and emittance measurements with a range of sensors. Remote sensing continues to evolve as a valuable agronomic tool that provides information to scientists, consultants, and producers about the status of their crops. This area is still relatively new compared with other agronomic fields; however, the information content is providing valuable insights into improved management decisions. This article details the current status of our understanding of how reflectance and emittance have been used to quantitatively assess agronomic parameters and some of the challenges facing future generations of scientists seeking to further advance remote sensing for agronomic applications.

$\mathrm{R}^{\mathrm{c}}$ emote sensing was not envisioned a century ago when the American Society of Agronomy was formed. However, individuals at that time used their eyes and understanding of plants to provide qualitative assessments of vegetative characteristics, vigor, color, and so forth. The development of sensors to measure spectral reflectance or emittance created opportunities to quantitatively describe agronomic parameters and during the past $100 \mathrm{yr}$ the application of remote sensing to agronomic problems created new methods for improved management of crops. Use of the visible and near-infrared portions of the electromagnetic spectrum for remote sensing have their roots in pioneering work by William Allen, David Gates, Harold Gausman, and Joseph Woolley, who provided much of the basic theory relating morphological characteristics of crop plants to their optical properties (Gates et al., 1965; Allen et al., 1969; Gausman et al., 1969a; Woolley, 1971; Allen et al., 1973; Gausman, 1973, 1974; Gausman et al., 1971, 1974; Gausman, 1977). High resolution spectral signatures of natural

J.L. Hatfield, USDA-ARS National Soil Tilth Lab., 2110 University Blvd., Ames, IA 50011; A.A. Gitelson, CALMIT, School of Natural Resources, Univ. of Nebraska, Lincoln, NE 68583; J.S. Schepers, USDA-ARS Soil and Water Conservation Unit, 120 Keim Hall, Univ. of Nebraska, Lincoln, NE 68583; C.L. Walthall, USDA-ARS, National Program Staff, 5601 Sunnyside Ave., Beltsville, MD 20705. Received 30 Dec. 2006. *Corresponding author (jerry.hatfield@ars.usda.gov).

Published in Agron. J. 100:S-117-S-131 (2008). doi:10.2134/agronj2006.0370c

Copyright $@ 2008$ by the American Society of Agronomy, 677 South Segoe Road, Madison, WI 53711. All rights reserved. No part of this periodical may be reproduced or transmitted in any form or by any means, electronic or mechanical, including photocopying, recording, or any information storage and retrieval system, without permission in writing from the publisher.

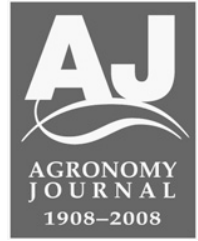

and cultivated species were presented as sources of information about normal plant growth and conditions caused by nutrient deficiency, pests, and abiotic stresses (Gausman and Allen, 1973; Gausman and Hart, 1974; Gausman et al., 1975a, 1976, 1978, 1981; Peynado et al., 1980). Research on the contributions of plant canopy architecture, solar illumination conditions and soil reflectance and emittance has further refined remote sensing as a tool for research and applications to agronomic problems (Suits, 1972; Tucker, 1977; Bauer et al., 1986; Liang, 2004). A summary of the progress in remote sensing applied to agriculture was recently published in a collection of articles in Photogrammetric Engineering and Remote Sensing (volume 69). Sensor techniques were described by Barnes et al. (2003), hydrometeorological applications detailed by Kustas et al. (2003), crop management applications by Pinter et al. (2003), crop yield assessment by Doraiswamy et al. (2004), applications to rangeland assessment and management by Hunt et al. (2003),

\footnotetext{
Abbreviations: Anth, anthocyanin; ARVI, atmospherically resistant vegetative index; $\mathrm{BRDF}$, bidirectional reflectance distribution function; Car, carotenoids content; Chl, chlorophyll; CWSI, Crop Water Stress Index; DisALEXI, Disaggregation Atmosphere-Land Exchange Inverse; DVI, Difference Vegetative Index; ET, evapotranspiration; GLAI, green leaf area index; GPP, gross primary production; LAD, leaf angle distribution; LAI, leaf area index; NDVI, Normalized Difference Vegetative Index; NDWI, Normalized Difference Water Index; NIR, near infrared; NRI, Normalized Reflectance Index; NN neural network; OSAVI, Optimized soil-adjusted vegetative index; PRI, Photochemical Reflectance Index; PVI, Perpendicular Vegetative Index; RT, radiative transfer models; RT-NN radiative transferneural network; SAIL, scattering by arbitrarily inclined leaves; SAVI, soiladjusted vegetative index; SDD, stress degree day; SIPI, structure-insensitive pigment index; SPAD, Soil-Plant Analyses Development; STD, standard deviation; SWIR, short-wave infrared; TSAVI, Transformed Soil Adjusted Vegetative Index; VF, vegetation fraction; VIs, vegetative indices; WDI, Water Deficit Index.
} 
water quality assessment by Ritchie et al. (2003), and sensor development and correction methods was prepared by Moran et al. (2003). Another recent review of the application of remote sensing methods to dryland crops was developed by Hatfield et al. (2004). These articles provide a summary of efforts in more detail than is possible in this article, and the reader is referred to those efforts for more thorough reading.

Instrumentation refinements and development of relationships between reflectance and plant responses have expanded our ability to quantify agronomic parameters. The basic principles of leaf and plant canopy reflectance have been incorporated into vegetative indices relating specific waveband combinations to various plant characteristics. Leaf emittance is related to leaf temperature, which has been extensively used to quantify plant stress and improve water management. Remote sensing uses more than visible, near-infrared, and thermal bands. Other portions of the electromagnetic radiation spectrum - for example, short-wave infrared (SWIR) and microwave-have been applied to agricultural problems. This article details the current status of our understanding of how reflectance and emittance have been used to quantitatively assess agronomic parameters and some of the challenges facing future generations of scientists seeking to further advance remote sensing for agronomic applications.

Advances in the application of remote sensing principles to agronomy were made possible by first understanding the spectral responses of individual leaves and then applying that knowledge to canopies. Although, we tend to use vegetative indices (VIs) as commonplace tools for crop assessment today, it is instructive to first develop an understanding of the processes that occur at the leaf level and the information content of these signals. Throughout this article we link canopy level responses to reflectance and emittance as measured by passive systems. As it is not possible to cover every aspect of remote sensing, our focus will be on remote sensing of information useful for addressing agronomic applications.

\section{ASSESSMENT OF LEAF PIGMENTS AS THE BASIS OF REMOTE SENSING}

Knowledge of leaf and canopy reflectance has fostered development and applications of remote sensing for agriculture. Central to applications of remote sensing to agriculture are fundamental observations of the plant leaf and the extensions of these relationships to the canopy.

Leaves contain chlorophyll, $\mathrm{Chl} a$ and $\mathrm{Chl} b$, as essential pigments for the conversion of light energy to stored chemical energy. The amount of solar radiation absorbed by a leaf is a function of the photosynthetic pigment content. Thus, Chl content can directly determine photosynthetic potential and primary production (e.g., Curran et al., 1990; Filella et al., 1995). Additionally, Chl gives an indirect estimation of the nutrient status as considerable leaf $\mathrm{N}$ is incorporated in $\mathrm{Chl}$ (Filella et al., 1995; Moran et al., 2000). Leaf chlorophyll content is closely related to plant stress and senescence (Hendry et al., 1987; Merzlyak and Gitelson, 1995; Peñuelas and Filella, 1998; Merzlyak et al., 1999; Carter and Knapp, 2001).

Carotenoids as chlorophylls are the main pigments of green leaves. Several specific physiological functions have been attributed to carotenoids because of their unique physicochemical and photophysical properties: a structural role in the organization of photosynthetic membranes; participation in light harvesting, energy transfer, quenching of chlorophyll excited states and singlet oxygen; and interception of deleterious free oxygen and organic radicals. Changes of leaf carotenoid content and their proportion to $\mathrm{Chl}$ are widely used for diagnosing the physiological state of plants during development, senescence, acclimation, and adaptation to different environments and stresses (e.g., Demmig-Adams et al., 1996; Young and Britton, 1990).

Anthocyanins are water-soluble vacuolar pigments of higher plants abundant in juvenile and senescing plants. Significant accumulation of anthocyanins in plant leaves is often induced as a result of environmental stresses, for example, strong sunlight, UV-B-irradiation, low temperature, drought, wounding, bacterial and fungal infections, $\mathrm{N}$ and $\mathrm{P}$ deficiencies, herbicides, and pollutants (e.g., Chalker-Scott, 1999). Since anthocyanins serve as indicators of stress for many plant species, their detection and quantitative assessment provides information about response and adaptation of plants to environmental stresses.

Traditionally, pigment analysis is conducted using wet chemical leaf extraction methods with organic solvents and spectrophotometric determination in solution (e.g., Lichtenthaler, 1987). This extraction technique, long considered the standard method for Chl assessment, requires destructive sampling (thus preventing developmental studies of single leaves) and is time consuming.

Hand-held Chl absorbance meters, of which several are available, measure leaf transmittance at two wavelengths in the red $(\sim 660 \mathrm{~nm})$ and near infrared (NIR; $940 \mathrm{~nm})$. The theoretical principles of these meters are described by Markwell et al. (1995). The application of reflectance spectroscopy to the estimation of leaf pigment content has recently received considerable attention. Vegetation indices that combine reflectance from a few spectral bands have been developed for pigment retrieval (e.g., Curran et al., 1990; Gitelson and Merzlyak, 1994, 1996; Gitelson et al., 1996a, 1996b; Blackburn, 1998; Datt, 1998; Adams et al., 1999; Gamon and Surfus, 1999). The indices are based on knowledge of the reflectance properties of leaf biochemical components. More complete reviews of the practical and theoretical considerations of reflectance spectroscopy are given by Curran et al. (1990); Gamon and Surfus (1999); and Le Maire et al. (2004). Compared with hand-held Chl meters, which yield a single index value, reflectance spectroscopy offers a wealth of information. Besides Chl, the many wavelengths of reflectance spectroscopy provide the basis for calculating the content of other pigments. However, a key problem is selection of an appropriate index from among the vast array of those available.

\section{Chlorophyll Content}

Remote sensing tools have been constructed on the principal that pigment content strongly affects leaf absorption spectra (Fig. 1). With increased Chl content, visible wavelength absorption increases, reaching more than $90 \%$ in the blue (400-500 $\mathrm{nm})$ region by both chlorophylls $a$ and $b$ and carotenoids and the red $(\sim 670 \mathrm{~nm})$ region where both chlorophylls absorb. Specific absorption coefficients of pigments are high for blue and red wavelengths, (e.g., Heath, 1969; Lichtenthaler, 1987) and the depth of light penetration into the leaf is very low 
(Kumar and Silva, 1973; Cui et al., 1991; Vogelmann et al., 1991; Vogelmann, 1993; Fukshansky et al., 1993; Merzlyak and Gitelson, 1995). As a result, even low amounts of pigments are sufficient to saturate absorption. For yellowish-green leaves when Chl exceeds $100 \mathrm{mg} \mathrm{m}^{-2}$, total absorption can exceed $90 \%$, depth of light penetration drastically decreases, and a further increase of pigment content does not cause increased total absorption (Fig. 1). Thus, the relationship of absorption vs. total Chl reaches a plateau, and absorption becomes virtually insensitive to further Chl increases (e.g., Thomas and Gausman, 1977; Gausman, 1984; Chappelle et al., 1992; Buschmann and Nagel, 1993; Gitelson and Merzlyak, 1994, Gamon and Surfus, 1999). The closer the wavelength is to the main absorption wavelength of pigments (blue or red), the lower the Chl content at which saturation of absorption vs. Chl relationship appears.

For the green $(\sim 550 \mathrm{~nm})$ and red edge $(\sim 700 \mathrm{~nm})$ regions, the absorption coefficient of chlorophylls in extract is very low and seldom exceeds $6 \%$ of that for blue and red (e.g., Lichtenthaler, 1987); however, green leaves absorb more than $80 \%$ of incident light in these spectral ranges (e.g., Moss and Loomis, 1952; Heath, 1969; Gausman et al., 1969b; Gausman and Allen, 1973; Gitelson and Merzlyak, 1994). For green and red edge wavelengths, depth of light penetration into the leaf was found to be four- to six-fold higher than for the blue and red (e.g., Fukshansky et al., 1993; Fig. 2 in Merzlyak and Gitelson, 1995). Therefore, sensitivity of absorption to $\mathrm{Chl}$ content is much higher in these spectral regions than for the blue and red.

Visible wavelength leaf reflectance decreases with increasing leaf greenness/Chl content (Fig. 2). While leaf color may vary from yellow-green to dark-green, blue reflectance is virtually insensitive to leaf greenness, typically remaining below $7 \%$. With increases of Chl from 50 to $100 \mathrm{mg} \mathrm{m}^{-2}$ (yellow to yellowgreen leaves), red reflectance decreases and when $\mathrm{Chl}>100 \mathrm{mg} \mathrm{m}^{-2}$, red reflectance does not change much with further increases of Chl (Fig. 3). Only reflectance in the green and the red edge ranges are sensitive to the whole range of Chl variation (Fig. 3 ); the standard deviation of reflectance (STD) has the highest values in the green between 530 and $590 \mathrm{~nm}$ and in the red edge around $710 \mathrm{~nm}$ (Fig. 2). Reflectance varies slightly in the NIR mainly due to leaf internal structure and thickness changes.

Thus, common spectral features of leaf absorption and reflectance are: (i) minimum sensitivity to pigment content in the blue between 400 and $500 \mathrm{~nm}$ and in the NIR; (ii) both absorption and reflectance of leaves with moderate to high $\mathrm{Chl}$ are essentially insensitive to $\mathrm{Chl}$ content in the red absorption band of chlorophyll $a$ near $670 \mathrm{~nm}$; (iii) the green and red

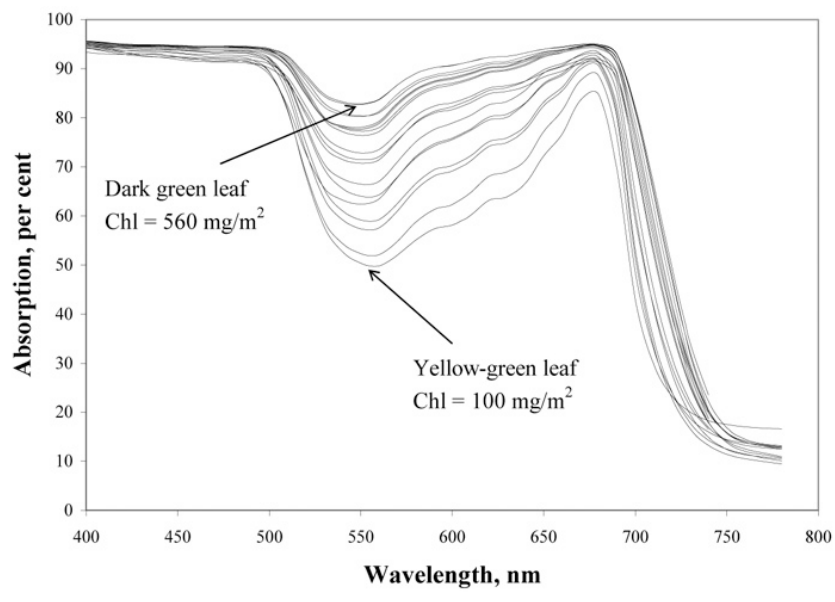

Fig. I.Absorption spectra of maize leaves.

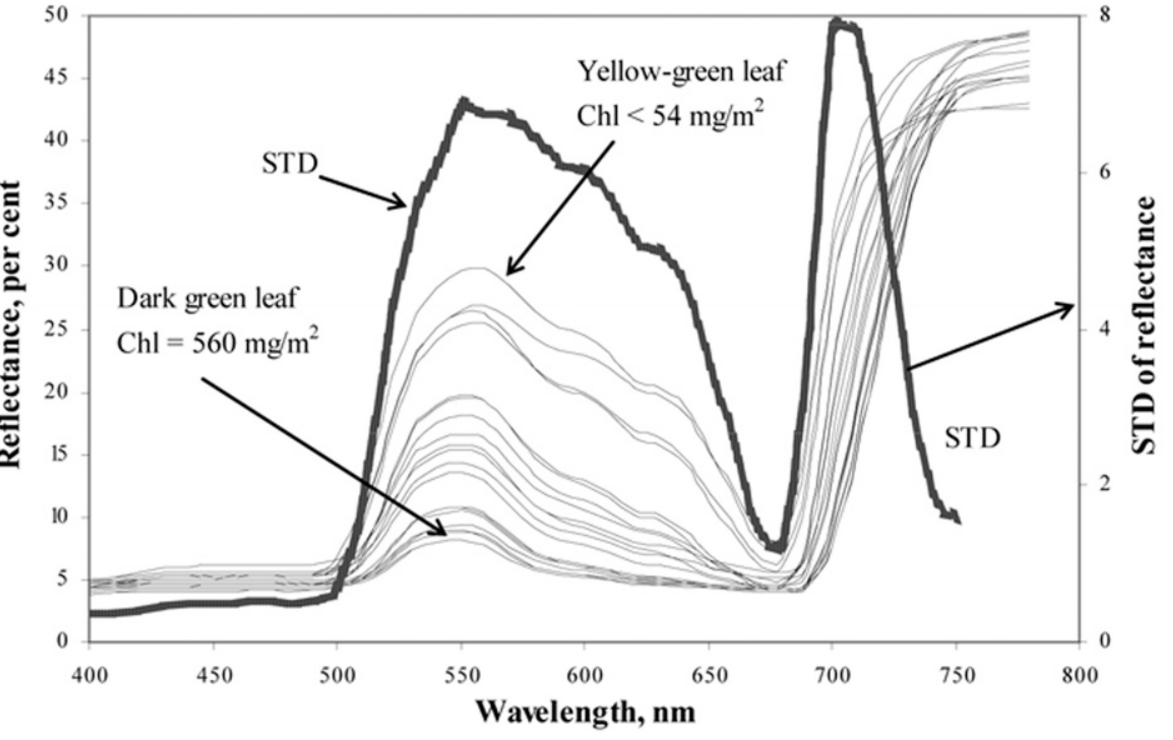

ig. 2. Reflectance spectra of maize leaves and standard deviation of reflectance. 


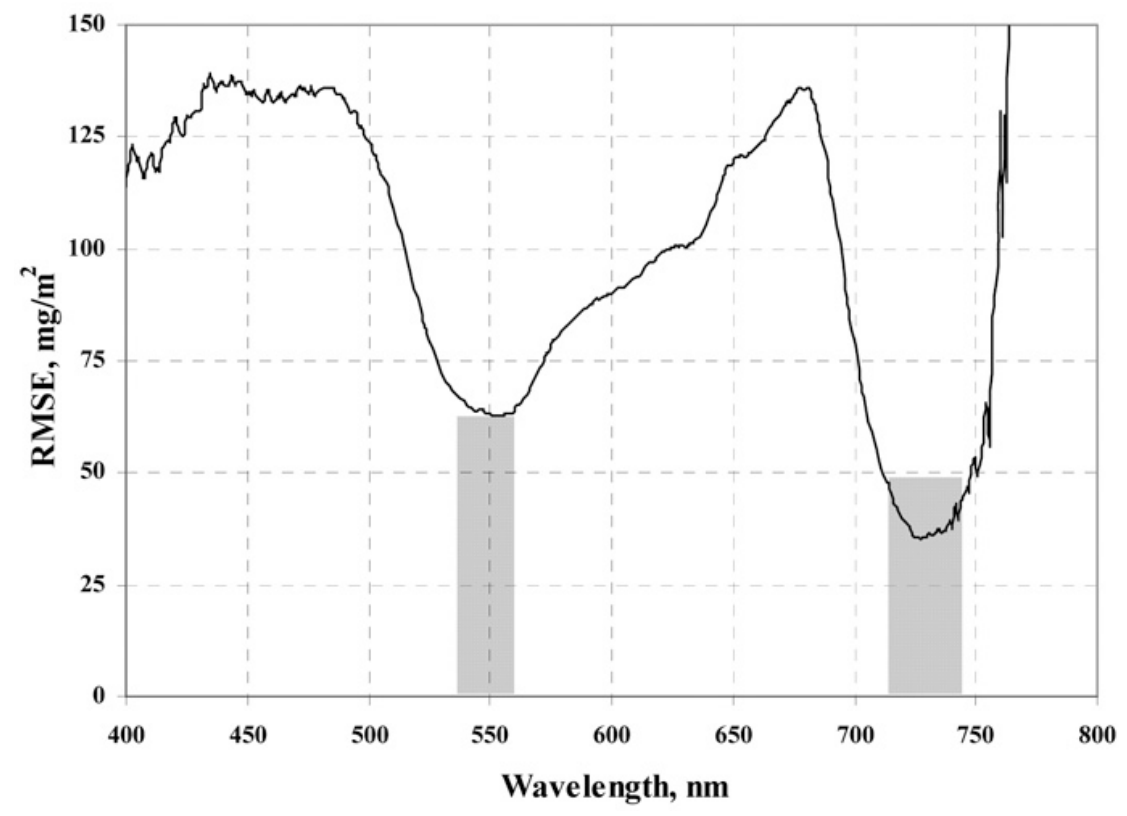

Fig. 4. Root mean square error of Chl estimation using chlorophyll index in the form $C I_{\lambda}=\left(R_{N I R} / R_{\lambda}-1\right)$ in maize leaves plotted vs. wavelength $\lambda$ when leaf $C h l$ ranged from 10 to $800 \mathrm{mg} / \mathrm{m}^{2}$. chlorophyll retrieval are not based on Chl maximum absorption wavelengths. Indices composed of Chl maximum absorption wavelengths would rapidly saturate, even with low chlorophyll concentrations. Moreover, other pigments also absorb in the blue region (e.g., Blackburn, 1998; Gitelson et al., 1996a, 2002a; Mariotti et al., 1996). These wavelengths place a severe limitation on their exclusive use to quantify plant response to stress.

Use of green and red edge wavelengths avoid saturation and the accompanying loss of sensitivity to Chl, and are usually preferred because reflectances are more sensitive to moderate to high chlorophyll content. Indices based at these spectral bands were proposed and used to estimate $\mathrm{Chl}$ content in the leaves of various plant species (Chappelle et al., 1992; Gitelson and Merzlyak, 1994, 1996; Gitelson et al., 1996a, 1996b, 2003a; 1999; Lichtenthaler et al., 1996; Gamon and Surfus, 1999; Sims and Gamon, 2002; Richardson et al., 2002; Le Maire et al., 2004). edge reflectances are related very closely hyperbolically for a wide range of leaf greenness (Chappelle et al., 1992; Gitelson and Merzlyak, 1994); and (iv) the highest sensitivity of reflectance and absorption to pigment variation is in the green from 530 to $590 \mathrm{~nm}$ and in the red edge around $700 \mathrm{~nm}$ (Fig. 1, 2, 3, and 4 ).

These fundamental spectral features of absorption and reflectance are widely recognized (Thomas and Gausman, 1977; Gausman, 1984; Chappelle et al., 1992; Buschmann and Nagel, 1993; Gitelson and Merzlyak, 1994, 1996, Gitelson et al., 1996a, 2003a) and are why algorithms for nondestructive

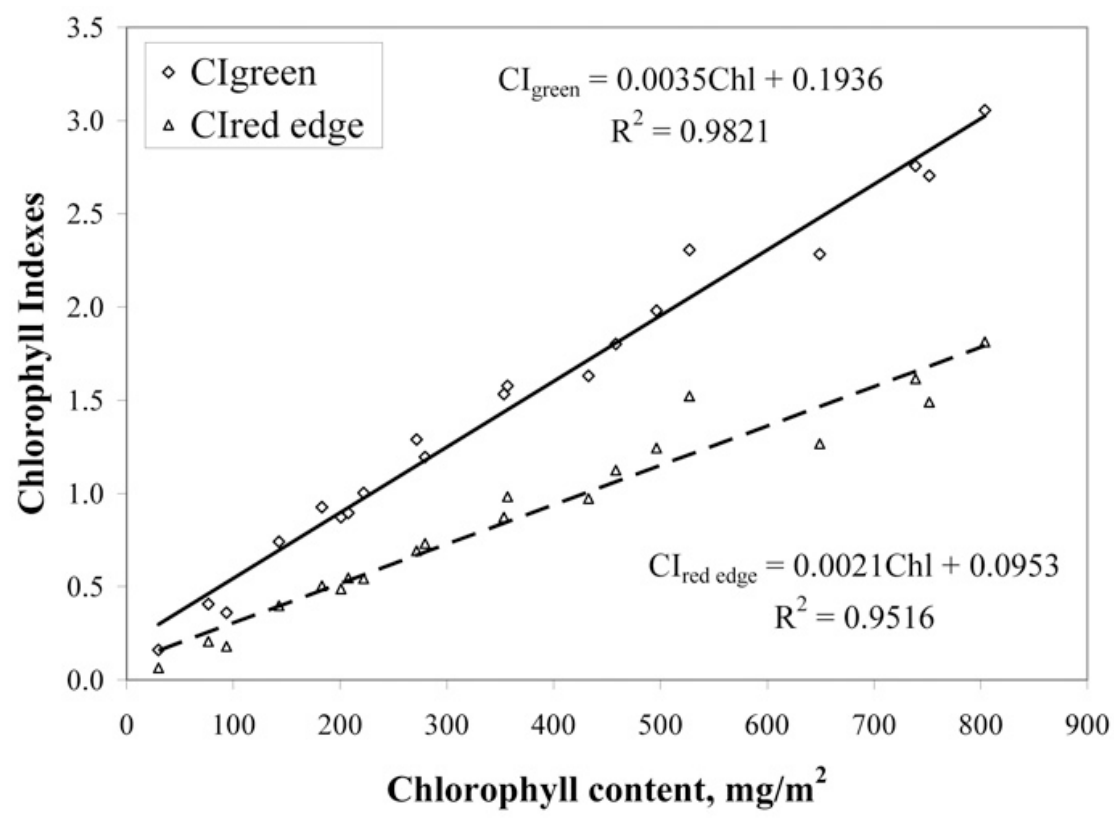

Fig. 5. Relationships between estimated and actually measured $\mathrm{Chl}$ content in maize leaves using chlorophyll Indices $\mathrm{Cl}_{\text {red edge }}=\left(\mathbf{R}_{\mathrm{NIR}} / \mathbf{R}_{\text {red edge }}\right)-I$ and $\mathrm{Cl}_{\text {green }}=\left(\mathbf{R}_{\mathrm{NIR}} I\right.$ $R_{\text {green }}$ ) - I where green band is between 540 and $560 \mathrm{~nm}$ and red edge band is between 705 and 725 nm (Gitelson et al., 2003a, 2005).

\section{Carotenoids and Anthocyanin Content}

Carotenoids content (Car) estimation is more difficult than Chl estimation. Chappelle et al. (1992) used ratio analysis of reflectance spectra to find a spectral band sensitive to pigment content. They recommended using a ratio $\mathrm{R}_{760} / \mathrm{R}_{500}$, where $R_{760}$ and $R_{500}$ are the reflectances at 760 and $500 \mathrm{~nm}$, respectively, as a quantitative measure of Car. Blackburn (1998) suggested that the optimal waveband for Car estimation is located at $470 \mathrm{~nm}$ and used so-called the pigment-specific ratio $\mathrm{R}_{800} /$ $\mathrm{R}_{470}$ and a pigment-specific normalized difference $\left(\mathrm{R}_{800}-\right.$ $\left.\mathrm{R}_{470}\right) /\left(\mathrm{R}_{800}+\mathrm{R}_{470}\right)$ for Car content retrieval. Penuelas et al.

(1995) proposed using a structure-insensitive pigment index $(S I P I)=\left(R_{800}-R_{445}\right) /\left(R_{800}\right.$ $\left.-\mathrm{R}_{680}\right)$. Sims and Gamon (2002) tested the above indices and have found none provided a significant correlation across the whole range of carotenoid/chlorophyll ratios. Total carotenoid content was closely related to total Chl content and the $\mathrm{Chl}$ indices were the best predictors of total Car content (Fig. 5). However, within the general relationship between Car and Chl there was substantial variation of the Car/Chl ratio. They recommended the Photochemical Reflectance Index $(P R I)=\left(R_{570}-R_{531}\right) /\left(R_{570}+R_{531}\right)$ (Gamon et al., 1992) as a proxy of Car/Chl ratio.

For anthocyanin (Anth) estimation, Gamon and Surfus (1999) used a ratio of red to green reflectances $\mathrm{R}_{600-700} / \mathrm{R}_{500-600}$. However, Sims and Gamon (2002) concluded, "estimation of carotenoid and anthocyanin contents remains more difficult than estimation of chlorophyll content." A problem with estimating pigment content 
Hatfield, Gitelson, Schepers \& Walthall in Agronomy Journal (2008) 100: S-117-S-131. DOI: 10.2134/agronj2006.0370c.

Table I. Spectral bands for retrieving pigment content from leaf reflectance spectra using the model $\left[R(\lambda I)^{-1}-\mathbf{R}(\lambda 2)^{-1}\right] \times \mathbf{R}(\lambda 3) \infty$ Cpigment. For Anth-free leaves (Anth $<3 \mathrm{mg} \mathrm{m}^{-2}$ ), both the green and red edge bands can be used as $\lambda \mathrm{I}$ while for Anthcontaining leaves only red edge band can be used as $\lambda I$. For carotenoids estimation both the green and red edge bands can be used as $\lambda 2$.

\begin{tabular}{lccc}
\hline \multicolumn{1}{c}{ Pigment } & $\lambda_{1}$ & $\lambda_{2}$ & $\lambda_{3}$ \\
\hline Chlorophylls, Anth-free Chlorophylls, Anth-free & $540-560$ & $760-800$ & $760-800$ \\
& $690-720$ & $760-800$ & $760-800$ \\
Chlorophylls, Anth-cont & $690-720$ & $760-800$ & $760-800$ \\
Carotenoids carotenoids & $510-520$ & $540-560$ & $760-800$ \\
& $510-520$ & $690-710$ & $760-800$ \\
Anthocyanins & $540-560$ & $690-710$ & $760-800$ \\
\hline
\end{tabular}

$\mathrm{R}\left(\lambda_{1}\right)^{-1}-\mathrm{R}(\lambda)^{-1}$ was related closely to the pigment of interest but affected by leaf scattering. The third reflectance $\mathrm{R}\left(\lambda_{3}\right)$, where $\lambda_{3}$ was in the NIR range, was closely related to leaf scattering. Tuning spectral bands in accord with spectral properties of pigment of interest, optimal spectral bands $\lambda_{1}, \lambda_{2}$, and $\lambda_{3}$ were found for each pigment estimate (Table 1).

\section{VEGETATIVE INDICES}

Vegetative indices have been developed to relate reflectance from leaves or canopies with canopy characteristics. There are a range

using two-band indices is that a two-band index is confounded by other factors such as absorption by other pigments and leaf scattering, which also influence apparent leaf reflectance at the two wavelengths.

A new approach to estimate total Chl, Car, and Anth content in higher plant leaves was developed and tested for leaves from a number of crop and tree species (Gitelson et al., 2003a, 2006a). Conceptual model relates reflectances in three wavebands to content of the pigment content of interest $\left(C_{\text {pigment }}\right)$.

$$
\left[\mathrm{R}\left(\lambda_{1}\right)^{-1}-\mathrm{R}\left(\lambda_{2}\right)^{-1}\right] \times \mathrm{R}\left(\lambda_{3}\right) \infty C_{\text {pigment }}
$$

Reflectance in the first band $\lambda_{1}$ was maximally sensitive to pigment of interest: $\mathrm{Chl}$ in the red edge around $700 \mathrm{~nm}$ (for Anth-containing and Anth-free leaves) and green around 550 $\mathrm{nm}$ for Anth free leaves (Gitelson et al., 2003a), Car at $510 \mathrm{~nm}$ (Gitelson et al., 2002a), and Anth at $550 \mathrm{~nm}$ (Gitelson et al., $2001)$. However, $R\left(\lambda_{1}\right)$ was also affected by absorption by other pigments and leaf scattering. Reflectance $R\left(\lambda_{2}\right)$ was maximally sensitive to absorption by other pigments; thus, the difference of VIs that have been developed during the past $40 \mathrm{yr}$. Hatfield et al. (2004) summarized the development of VIs and their application to crop canopies. Many of the common ones are listed in Table 2 and the application of these will be summarized in the next section. At the canopy level, the changes of canopy reflectance are the largest in the near-infrared wavelengths throughout the growing season due to increase of biomass and, thus, scattering, whereas the visible portions of the spectrum show less, but significant, seasonal variation that relates to absorption of light by photosynthetic and photoprotective pigments (Fig. 6). Development of VIs can be traced back to Jordan (1969), who related the ratio of NIR $(800 \mathrm{~nm})$ to red $(675 \mathrm{~nm})$ reflectance (NIR/RED) to LAI. As a refinement, Tucker (1979) proposed a Difference Vegetative Index (DVI) as NIR-RED as a measure of vegetation changes over large areas and increased the confidence that VIs could be effectively used for large-scale assessment of crop canopies. Many of the current VIs are based on broad wavebands closely associated with the four LANDSAT satellite multispectral scanner wavebands. Jackson and Huete (1991) stated that the purpose of VIs was

Table 2. Summary of selected vegetation indices, wavebands, applications, and citations. $\dagger$

\begin{tabular}{|c|c|c|c|}
\hline Index & Wavebands & Application & Reference \\
\hline & $R_{800}-R_{680}$ & biomass & Jordan, 1969 \\
\hline & $R_{800}-R_{550}$ & biomass & Bushman and Nagel, 1993 \\
\hline & $\mathrm{R}_{550}$ & chlorophyll & Carter, 1994 \\
\hline & $\mathrm{R}^{-1} 700$ & & Gitelson et al., 1999 \\
\hline & $\log \left(I / R_{737}\right)$ & chlorophyll & Yoder and Pettigrew-Crosby, 1995 \\
\hline Simple ratio & $\mathrm{R}=\mathrm{R}_{\mathrm{NIR}} / \mathrm{R}_{\text {red }}$ & biomass, LAl, cover & Birth and McVey, 1968; Jordan, 1969 \\
\hline Photochemical Reflectance Index & $P R I=\left(R_{550}-R_{531}\right) /\left(R_{550}+R_{531}\right)$ & light capture efficiency & Gamon et al., 1992 \\
\hline Pigment-specific normalized difference & $\left(R_{800}-R_{470}\right) /\left(R_{800}+R_{470}\right)$ & LAI & Blackburn, 1998 \\
\hline Normalized Difference Vegetation Index & $N D V I=\left(R_{N I R}-R_{\text {red }}\right) /\left(R_{N I R}+R_{\text {red }}\right)$ & intercepted PAR, vegetation cover & Deering, 1978 \\
\hline Perpendicular Vegetative Index & $P V I=\left(R_{N I R}-a R_{r e d}-b\right) /\left(I+a^{2}\right)^{1 / 2}$ & LAI & Richardson and Wiegand, 1977 \\
\hline Wide Dynamic Range Vegetation Index & $W D R V I=\left(0 . I R_{N I R}-R_{\text {red }}\right) /\left(0 . I R_{N I R}+R_{\text {red }}\right)$ & LAI, vegetation cover, biomass & Gitelson, 2004 \\
\hline Soil Adjusted Vegetation Index & $S A V I=\left(R_{N I R}-R_{r e d}\right)(I+L) /\left(R_{N I R}+R_{r e d}+L\right)$ & LAl & Huete, 1988 \\
\hline Transformed Soil Adjusted Vegetative Index & $T S A V I=a\left(R_{N I R}-a R_{\text {red }}-b\right) /\left(R_{\text {red }}+a R_{N I R}-a b\right)$ & LAI, biomass & Baret et al., 1989 \\
\hline Enhanced Vegetation Index & $E V I=2.5\left(R_{\text {NIR }}-R_{\text {red }}\right) /\left(R_{N I R}+6 R_{\text {red }}-7.5 R_{\text {blue }}+1\right)$ & LAl, biomass & Huete et al., 2002 \\
\hline Green NDVI & $\left(R_{N I R}-R_{\text {green }}\right) /\left(R_{N I R}+R_{\text {green }}\right)$ & intercepted PAR, vegetation cover & $\begin{array}{l}\text { Bushman and Nagel, I993; Gitelson and } \\
\text { Merzlyak, I994; Gitelson et al., I } 996\end{array}$ \\
\hline Red Edge NDVI & $\left(R_{N I R}-R_{\text {red edge }}\right) /\left(R_{N I R}+R_{\text {red edge }}\right)$ & intercepted PAR, vegetation cover & Gitelson and Merzlyak, 1994 \\
\hline \multirow[t]{2}{*}{ Visible Atmospherically Resistant Indices } & $\mathrm{VARI}_{\text {green }}=\left(\mathrm{R}_{\text {green }}-\mathrm{R}_{\text {red }}\right) /\left(\mathrm{R}_{\text {green }}+\mathrm{R}_{\text {red }}\right)$ & green vegetation fraction & Gitelson et al., 2002b \\
\hline & $V A R I_{\text {red edge }}=\left(R_{\text {red edge }}-R_{\text {red }}\right) /\left(R_{\text {red edge }}+R_{\text {red }}\right)$ & green vegetation fraction & Gitelson et al., 2002b \\
\hline \multirow[t]{2}{*}{ Chlorophyll Indices } & $\mathrm{Cl}_{\text {green }}=\left(\mathrm{R}_{\mathrm{NIR}} / \mathrm{R}_{\text {green }}\right)-1$ & LAI, GPP, chlorophyll & Gitelson et al., 2003b, 2005 \\
\hline & $\mathrm{Cl}_{\text {red edge }}=\left(\mathrm{R}_{\mathrm{NIR}} / \mathrm{R}_{\text {red edge }}\right)-1$ & LAI, GPP, chlorophyll & Gitelson et al., 2003b, 2005 \\
\hline
\end{tabular}

† LAI, leaf area index; GPP, gross primary productivity. 


\section{Corn 2006}

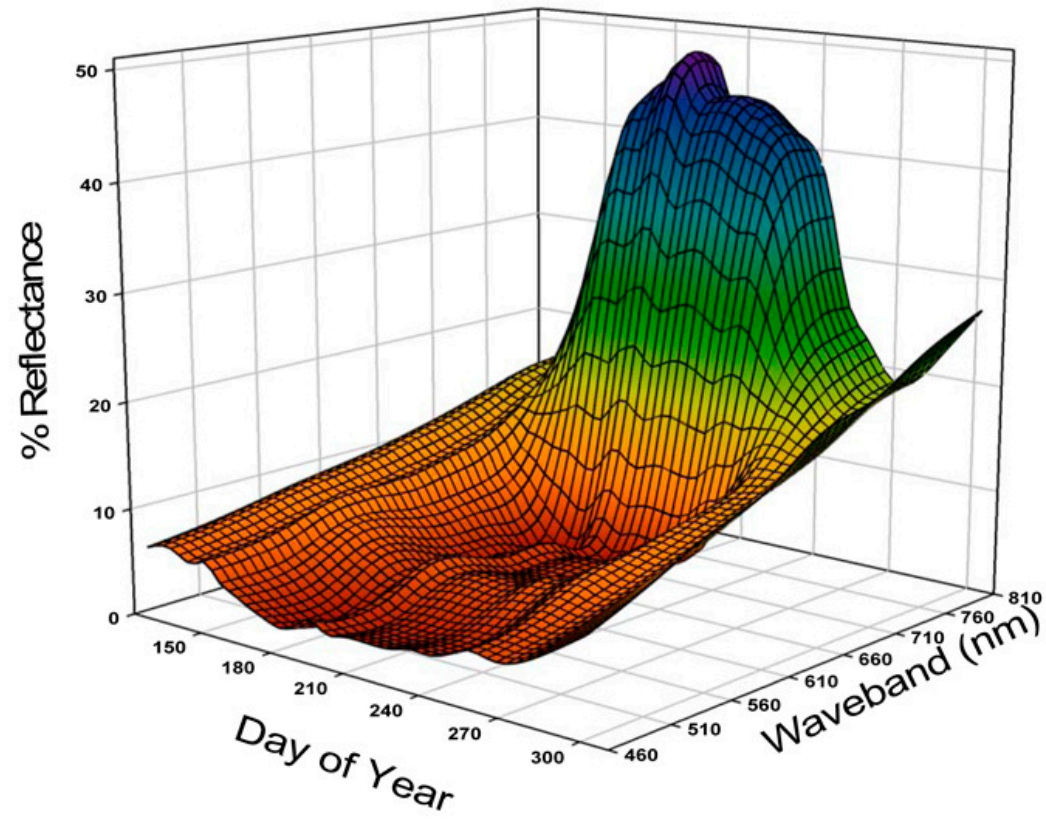

Fig. 6. Seasonal changes in the reflectance from a corn canopy using an eightband sensor.

to enhance the vegetation signal while minimizing the solar irradiance and soil background effects. Many current VIs have their foundation in leaf reflectance and understanding how these reflectance indices relate to canopy parameters will help strengthen our future efforts to refine and apply VIs to agronomic problems. The trend toward use of narrow-band hyperspectral indices is fostering a refinement of VIs and will increase our ability to exploit the information content of detailed leaf spectra. Part of this evolution is the wide use the red edge band and the extension beyond visible and near-infrared wavebands into the SWIR regions. The power of indices incorporating SWIR wavebands is yet to be realized.

\section{RETRIEVING AGRONOMIC PARAMETERS FROM PLANT CANOPIES}

Retrieval of plant canopy agronomic parameters poses a different problem from that of the retrieval of plant leaf parameters. Plant canopy reflectance integrates the contributions of leaf optical properties; reflectance of underlying surfaces such as soil, plant litter, and weeds; and plant canopy architecture (Gausman et al., 1975b; Norman et al., 1985; Verhoef, 1984; Norman and Welles, 1983). Plant canopy architecture is quantified in radiative transfer models (RT) as LAI, percentage vegetative cover, and leaf angle distribution (LAD) (Goel, 1988; Liang and Strahler, 2000; Liang, 2004). Illumination conditions, including the amount of direct vs. diffuse incoming solar radiation, and solar zenith and azimuth angles are important as these govern the amount and intensity of shadowing within the canopy. The cumulative effect of these additional factors is that transfer of information from leaf reflectance to canopy reflectance is nonlinear. View angle considerations are important when viewing off-nadir, including situations where wide view angle swath widths are used to maximize ground area coverage. The bidirectional reflectance distribution function (BRDF), a fundamental quantity describing the reflectance from a surface from all possible viewing angles under all possible illumination conditions, has seen considerable study for plants and soils (Liang and Strahler, 2000; Walthall et al., 1985) and can be approached as a source of information as well as a source of noise to be removed from remotely sensed data

The most widely used VI is the Normalized Difference Vegetative Index (NDVI) proposed by Deering (1978) that now serves as somewhat of a benchmark for researchers developing new VIs. The NDVI has been shown to be strongly related to light interception (Hatfield et al., 1984a; Redelfs et al., 1987; Richardson et al., 1992; Sellers, 1987; Serrano et al., 2000; Verma et al., 1992; Wiegand and Hatfield, 1988; Wiegand et al., 1990, 1992; Russel et al., 1995). Interference from underlying soil reflectance, especially for incomplete canopy cover, has been a weakness for many VIs. The reflectance line for the soil (day of year 150) shown in Fig. 6 reveals a fairly linear relationship across the wavelengths compared with the changes as the canopy develops. Agronomic systems occur on many different soils and accounting for these differences provides confidence in being able to apply VIs to different regions. Minimizing the soil background effect has been accomplished by a number of methods. Kauth and Thomas (1976) proposed a linear combination of four wavebands using principal component analyses to estimate brightness, greenness, yellowness, and other components. The brightness term represents the magnitude of the reflected energy and could be considered a soil background line. The greenness term represents an orthogonal plane to the soil line that contained information about vegetation and represents yellowness - an additional plane to both soils and vegetation with particular sensitivity to senescent vegetation. Jackson (1983) described how spectral indices could be obtained from combinations of wavebands in $n$-space. Another attempt to remove soil background was the Perpendicular Vegetative Index (PVI) developed by Richardson and Wiegand (1977) using a statistical relationship. A review of the refinements of ratio-based VIs to account for soil background through a soil-adjusted vegetative index (SAVI) was described by Huete (1988). Many of the soil background adjustment approaches have been accomplished through the use of vegetative indices in which the coefficients were derived from empirical studies. Rondeaux et al. (1996) proposed an Optimized SAVI (OSAVI) in which the "l" term (an adjustment factor for soil reflectance), was equal to 0.16 . An additional adjustment for soil background to the NDVI was developed by Baret et al. (1989) and expressed as the Transformed Soil Adjusted Vegetative Index (TSAVI). An atmospherically resistant VI, (ARVI), was proposed for the use of satellite data (Kaufman and Tanré, 1992), and further modified by Huete et al. (1997) to make the soil adjusted (SARVI2).

Recently, a suite of algorithms was developed for accurate estimation of crop biophysical characteristics. The suite includes algorithms for retrieval of crop green vegetation fraction (VF), fraction of PAR absorbed by photosynthetically active 
vegetation $\left(\right.$ fAPAR $\left._{\mathrm{PH}}\right)$, green leaf area index (GLAI), green leaf biomass, total Chl content, and gross primary production (GPP) (Wiegand and Richardson, 1984, Wiegand et al., 1979). Detecting changes of growth and development or yield across different species, growing seasons, or locations requires methods that utilize the same wavebands or patterns (Shanahan et al., 2001).

Daughtry et al. (2000) combined VIs minimizing background reflectance contributions with VIs responding more to leaf $\mathrm{Chl}$ content in a simulation study to produce isolines of leaf Chl content. A limited test of the concept using canopy reflectance data showed that the slopes of the VI pairs were linearly related to leaf $\mathrm{Chl}$ content over a wide range of foliage cover and background reflectances.

Leaf area index (LAI), Chl content, and biomass are important crop biophysical characteristics used for climate modeling, estimating primary production, and forecasting crop yield. Algorithms for green LAI and green leaf biomass estimation (Green Leaf Area Vegetation Index), are summarized in Gitelson et al. (2003b; 2005). These algorithms, which have been tested in maize (Zea mays L.), soybean [Glycine max (L.) Merr.], and wheat (Triticum aestivum L.), allow accurate prediction of GLAI ranging from 0 to more than $6 \mathrm{~m}^{2} \mathrm{~m}^{-2}$ with RMSE of GLAI prediction of less that $0.6 \mathrm{~m}^{2} \mathrm{~m}^{-2}$.

The same algorithms were parameterized for remote assessment of green leaf biomass (Gitelson et al., 2003b) and total $\mathrm{Chl}$ content in irrigated and rainfed maize and soybean (Gitelson et al., 2005). The algorithm accounted for more than $98 \%$ of green leaf biomass variation in the range from 100 to more than $3000 \mathrm{~kg} \mathrm{ha}^{-1}$. When applied for total Chl estimation in crops, the algorithm accounted for more than $92 \%$ of $\mathrm{Chl}_{t}$ variation in both soybean and maize. However, in discrete spectral bands 540 to $560 \mathrm{~nm}$ and 700 to $710 \mathrm{~nm}$ the calibration coefficients in both algorithms remained species-specific. Difference between species was more pronounced in the green than the red-edge model (Fig. 6 in Gitelson et al., 2005). Such behavior is understandable, if one takes into account very contrasting canopy architectures and leaf structures of maize and soybean. A spectral range, where the algorithm is non-species specific, has been found applying a procedure that tuned spectral bands in the model in accord with spectral characteristics of the media (Gitelson et al., 2003a, 2006a). The algorithm $\left[\left(\mathrm{R}_{840-870} / \mathrm{R}_{720-730}\right)-1\right]$ predicted total $\mathrm{Chl}$ in maize and soybean ranged from 0.03 to $4.33 \mathrm{~g} \mathrm{~m}^{-2}$ with a RMSE of less than $0.32 \mathrm{~g} \mathrm{~m}^{-2}$ for both species considered together. During subsequent work, Gitelson et al. (2006b) found that GPP relates closely to total chlorophyll content in maize and soybean. Total $\mathrm{Chl}$ accounts for more than $98 \%$ of GPP ranged from 0 to $3.1 \mathrm{mg} \mathrm{CO}_{2} \mathrm{~m}^{-2} \mathrm{~s}^{-1}$. The algorithm for GPP estimation (Gitelson et al., 2003c, 2006b) provided accurate estimates of midday GPP in both crops under rainfed and irrigated conditions with RMSE of GPP estimation of less than $0.3 \mathrm{mg} \mathrm{CO} 2$ $\mathrm{m}^{-2} \mathrm{~s}^{-1}$ in maize (GPP ranged from 0 to $3.1 \mathrm{mg} \mathrm{CO}_{2} \mathrm{~m}^{-2} \mathrm{~s}^{-1}$ ) and less than $0.2 \mathrm{mg} \mathrm{CO}_{2} \mathrm{~m}^{-2} \mathrm{~s}^{-1}$ in soybean (GPP ranged from 0 to $1.8 \mathrm{mg} \mathrm{CO}_{2} \mathrm{~m}^{-2} \mathrm{~s}^{-1}$ ). Validation using independent data sets for irrigated and rainfed maize showed robustness of the technique; RMSE of GPP prediction was less than $0.27 \mathrm{mg}$ $\mathrm{CO}_{2} \mathrm{~m}^{-2} \mathrm{~s}^{-1}$.

Quantification of vegetation stress using reflectance with cur- rent multispectral methods has shown limitations. Campbell et al. (2007) suggested that improvements could be achieved by using hyperspectral and fluorescence methods. They evaluated nitrogen, carbon dioxide, ozone, and ultraviolet radiation stresses on corn, soybean, and red maple (Acer rubra L.) and found that combinations of fluorescence and reflectance at specific wavebands improved the ability to detect these stresses. The continued advancement of the use of various wavelengths offers the potential to provide valuable information for agronomists to detect vegetation stress.

\section{APPLICATIONSTO AGRONOMIC PROBLEMS}

\section{Nitrogen}

Nitrogen is an essential nutrient for modern crop production; however, $\mathrm{N}$ is often over-applied without regard to crop requirements or potential environmental risk to ensure that acceptable crop yields are achieved. Increased $\mathrm{N}$ management has been shown to reduce $\mathrm{N}$ applications while maintaining or increasing crop yields. Early methods for $\mathrm{N}$ management have used the Soil-Plant Analyses Development (SPAD) chlorophyll meter, color photography, or canopy reflectance factors to assess $\mathrm{N}$ variations across grower's corn fields (Schepers et al., 1992, 1996; Blackmer et al., 1993, 1994, 1996a, 1996b; Blackmer and Schepers, 1996; Shanahan et al., 2003). These techniques were based on comparisons with readings obtained from an adequately fertilized strip in the same field and eliminated the requirements for prior knowledge of the relationship between nutrient concentration and crop reflectance.

An example of a direct method for $\mathrm{N}$ management was developed Bausch and Duke (1996) based on a N reflectance index (NRI) derived from green and NIR reflectance of an irrigated corn crop. The NRI was highly correlated with an N sufficiency index calculated from SPAD chlorophyll meter data and provided a rapid assessment of corn plant $\mathrm{N}$ status for mapping purposes a the field scale. Monitoring in-season plant $\mathrm{N}$ with the NRI reduced applied $\mathrm{N}$ via fertigation by $39 \mathrm{~kg} \mathrm{~N} \mathrm{ha}^{-1}$ without reducing grain yield (Bausch and Diker, 2001).

A more indirect approach was proposed by Raun et al. (2001), who found midseason estimates of potential yield winter wheat would help growers adjust topdress $\mathrm{N}$ applications. Their approach was based on preplant soil $\mathrm{N}$ tests, within season rates of mineralization, and projected $\mathrm{N}$ removal. Potential grain yields were estimated from several post-dormancy NDVI measurements normalized by the number of growing degree days accumulated between the observation dates. This adjusted for local weather and compensated for spatial variations in $\mathrm{N}$ requirements caused by soil differences and management, for example, stand establishment and early season growth.

\section{Phosphorus}

Phosphorus deficiency in plants can be expressed through color and biomass accumulation. Young plants growing in cold soils are the most likely to exhibit P deficiency symptoms, which are purple leaves in the case of corn. Colder soil temperatures limit root exploration, which is why starter fertilizer application at planting time is common for early seeded corn. Corn planted on the same soil after the soil has warmed up is not nearly as likely to show symptoms of P deficiency as that planted in 
colder soils. Plants frequently grow out of the early symptoms of a P deficiency (i.e., purplish leaves) but the effects may linger in terms of $\mathrm{N}$ and $\mathrm{P}$ concentration in vegetative tissue and yield. Osborne et al. (2004) showed that P deficiency in corn was significantly correlated with NIR and blue reflectance in highresolution aircraft imagery in Nebraska. Imagery was frequently less likely to detect P deficiency at silking than it was at the 6 to 8 leaf stage of corn. The obvious difficulty encountered with early season imagery of crops is dilution with soil background reflectance.

Real-time active sensors that monitor the appropriate wavebands offer an opportunity to use the crop as a bio-indicator of soil P availability. Such sensors mounted on field equipment could generate a map to guide soil sampling or would allow on-the-go variable-rate application of nutrients, assuming the causes of the plant symptoms are known.

\section{Soil Moisture}

Soil moisture has been a problem of critical importance in agronomic decisions and there have been many different attempts to directly measure soil moisture from remote sensing. Microwave with wavelengths around $21 \mathrm{~cm}$ has been used as the most common approach. Jackson and Schmugge (1989) described the use of passive microwave as a tool for measuring and mapping soil water content of the surface layer. Microwave wavelengths are capable of detecting soil moisture because of the large differences in the dielectric properties of water compared to other soil components. Sensing of soil moisture in the surface layer is a function of the wavelength and Jackson and Schmugge (1989) proposed that for the $\mathrm{L}$ band $(21 \mathrm{~cm})$ the effective depth of detecting soil moisture would be approximately $5 \mathrm{~cm}$. One of the problems with passive microwave systems is the relatively large footprint and for the L band system the spatial resolution may be on the order of $100 \mathrm{~km}$. This limits the ability to detect soil moisture in a specific field using a satellite-based approach. However, one advantage of microwave over all other remote sensing wavebands is the ability of these wavelengths to penetrate through clouds.

Retrieval of soil water content from passive microwave systems requires the following factors be addressed: the brightness temperature be normalized to emissivity, the effects or interference of vegetation above the soil surface be removed, adjustments for the soil roughness effects on brightness temperature be made, a relationship exist between soil dielectric properties and emissivity, and a relationship exists between soil dielectric properties and soil water content. As an illustration of the integration of various remote sensing parameters, Jackson et al. (1999) proposed using the NDVI to adjust the microwave signals for canopy density. One of the major problems in using microwave for soil water is the interference of the vegetative water content, and Jackson et al. (2004) compared the NDVI with the Normalized Difference Water Index (NDWI), which is defined as $\left(\mathrm{R}_{\mathrm{NIR}}-\mathrm{R}_{\text {SWIR }}\right) /\left(\mathrm{R}_{\mathrm{NIR}}+\mathrm{R}_{\text {SWIR }}\right)$. This index uses the SWIR wavebands to define the water content of the vegetation and showed a more robust relationship to vegetative water content than NDVI.

There continues to be advances in the development of sensors. For example, LaVine et al. (1994) demonstrated that syn- thetic aperature microwave radiometers could reduce the footprint size down to $10 \mathrm{~km}$. Further advances in technology may provide further reductions from satellite systems and provide real-time measurements of surface soil water content for inclusion in agronomic applications.

\section{EMITTANCE FROM CANOPIES AND CROP WATER STRESS}

Emittance from crop canopies is related to the temperature of the crop through the Stefan-Boltzman law where emittance is a function of the fourth power of surface temperature. Measurement of surface temperatures with infrared thermometers has become routine and offer the potential for crop water stress detection and water management. A summary of the history of measuring crop stress using the thermal $(8-4 \mu \mathrm{m})$ portion of the spectrum provides a glimpse into the potential applications of these data. The foundation for the current research can be traced to original observations by Tanner (1963), who found that plant temperature varied from air temperature and could be measured with thermocouples attached to the leaves. This was expanded to quantify the relationship among plant water stress, solar radiation, air temperature, and leaf temperature by Wiegand and Namken (1966). Wiegand and Namken (1966) and Ehler et al. (1978) provided the original observations that leaf temperature was related to plant moisture status. These findings prompted studies over the past $40 \mathrm{yr}$ to quantify crop stress and estimate water use based on observations of canopy temperature. Indices were developed for crop stress in a similar fashion to the VIs using terms such as stress degree day (SDD), Crop Water Stress Index, non-water-stressed baselines, thermal kinetic windows, crop specific temperatures, and Water Deficit Index appeared as quantitative measures of plant stress (Table 3). These advances were made possible by the development of affordable and reliable infrared thermometers that accurately measured canopy temperature without direct physical contact between the leaf and the thermometer.

Development of canopy temperature stress indices can be traced to Jackson et al. (1977), who found that canopy temperatures in wheat were a useful measure of crop water status. Variation of canopy-air temperature differences ( $\mathrm{Tc}-\mathrm{Ta}$ ) difference across crops and climates invoked a team of researchers led by Idso et al. (1981) to derive an empirical model for canopy stress, whereas Jackson et al. (1981) derived the more theoretical relationship between canopy temperature and crop stress. The critical relationship to define CWSI is the nonstressed lower baseline and is derived from the curves as per Table 3 (Jackson et al., 1981).

The Crop Water Stress Index (CWSI) has become one of the more widely used methods for quantifying crop stress. This approach has prompted a number of studies to evaluate the potential measurement problems in obtaining accurate values for all of the parameters needed to estimate CWSI (Gardner et al., 1992a, 1992b). Wanjura et al. (1990) found CWSI values were negatively correlated with grain sorghum [Sorghum bicolor (L.) Moench] and cotton (Gossypium hirsutum L.) yields with grain sorghum yields showing a higher sensitivity to CWSI than cotton lint yields. Variation among years was accounted for by normalizing each year relative to maximum yield for the loca- 
Hatfield, Gitelson, Schepers \& Walthall in Agronomy Journal (2008) 100: S-117-S-131. DOI: 10.2134/agronj2006.0370c.

Table 3. Summary of selected thermal indices, wavebands, applications, and citations.

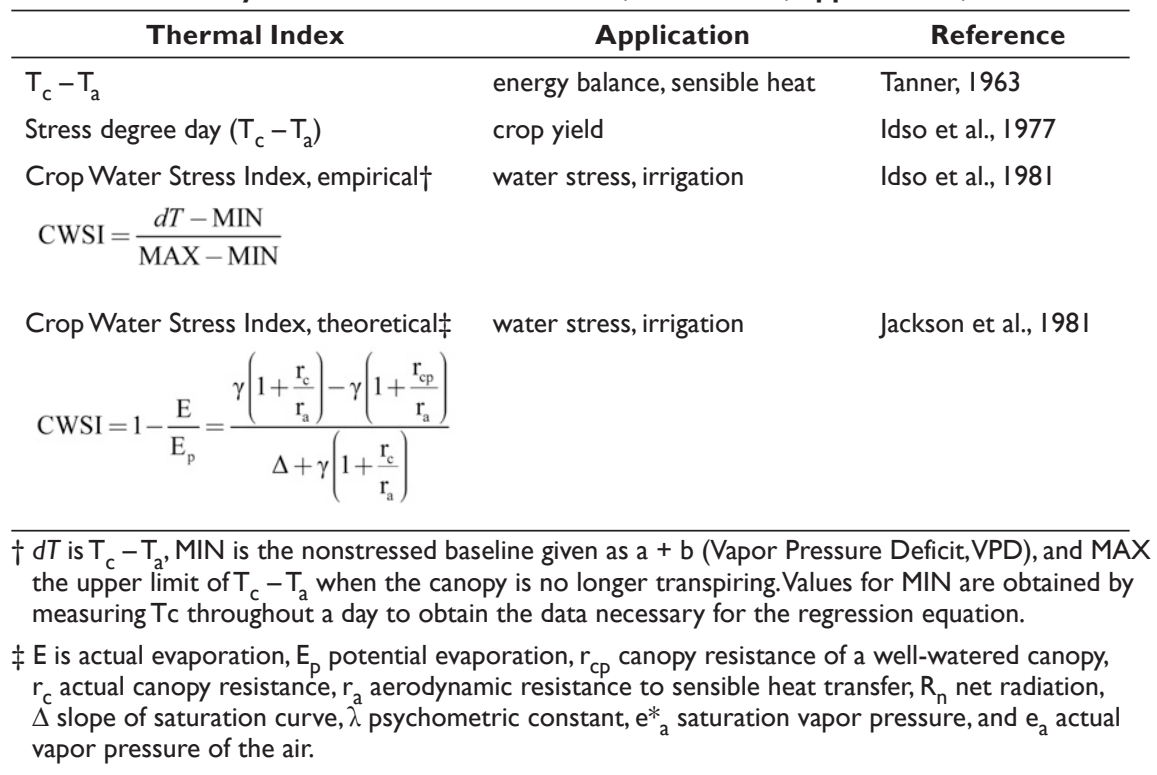

tion. Feldhake and Edwards (1992) used the CWSI concept to quantify water stress on orchardgrass (Dactylis glomerata L.) in the humid pasture areas of the United States. Wanjura and Upchurch (2000) compared the empirical (Idso et al., 1981) and theoretical CWSI (Jackson et al., 1981) for corn and cotton on the High Plains of Texas and found the empirical approach was slightly more accurate than the theoretical approach because of the bounds of 0 to 1.0 placed by the empirical method. Studies have shown that the simple SDD (midday air temperature-canopy temperature) were related to crop yield, for example, kidney bean (Phaseolus vulgaris L., Walker and Hatfield, 1979) and pigeonpea [Cajanus cajan (L.) Millsp., Patel et al., 2001]. These are only a few of the number of studies that have been conducted using this simple model.

Fundamental differences in the empirical approach must be recognized before these approaches can be used. As an example, comparison of the non-water-stressed baseline for 50 cotton strains revealed significant differences among strains (Hatfield et al., 1987). The genetic variation that exists in the relationship between water deficits and canopy temperature responses suggested that this approach could be used as a screening tool for genetic response to water stress. Genetic variations may create problems when applying this method to different canopies and care should be exercised in universally extending these relationships without first verifying the $T_{c}$ response for a range of canopy water deficits.

For areas with significant crop stress, such as those found in dryland environments, there has been the continuing problem of measuring canopy temperature under conditions of incomplete or partial ground cover (Hall et al., 1992; Vining and Blad, 1992). Heilman et al. (1981) demonstrated that incomplete groundcover provided a significant bias when estimating the true canopy temperature. This has been one of the major limitations of applying thermal infrared measurements to dryland canopies. Carlson et al. (1994) developed a method that incorporated thermal infrared measurements with NDVI to estimate soil water content and vegetation cover. Moran et al. (1994) developed a relationship referred to as the Water Deficit Index (WDI) that extended the CWSI theory to partially covered fields by using SAVI as a measure of canopy cover. Development of the trapezoid that covers the range of well-watered to completely stressed vegetation across the range of canopy sizes is based on the ratio of actual to potential evaporation, the same foundation as the CWSI. This approach offers potential as a method for quantifying water stress under conditions of partial cover. A recent study by DeTar et al. (2006) coupled CWSI with NDVI to measure water stress in full canopy cotton and found a good relationship using NDVI values derived using 686 and $850 \mathrm{~nm}$ wavebands. These approaches are different than the integration of VIs and thermal radiance into a yield prediction model developed by Hatfield (1983). Hatfield (1983) derived an estimate of biomass at the onset of the reproductive stage by VI and then a $\mathrm{T}_{\mathrm{c}}-$ derived measure of stress used to determine whether the plant was able to maintain optimal growing conditions during grain-filling by measuring the thermal stress of the crop. The premise of this approach is based on the observation that the faster the rate of decline of VIs during grain-filling, the lower the yield caused by hastened phenological development.

Confounding the observations of canopy temperature in wheat during grain-filling was caused by the presence of the panicles because the nontranspiring panicle at the top of the canopy artificially increased the canopy temperature (Hatfield et al., 1984d). In nonwater stressed canopy, the presence of the panicles increased the observed canopy temperature by $2^{\circ} \mathrm{C}$ when viewed at an oblique angle. Increasing the angle of measurement from nadir provided a solution for this bias; however, users of this technology need to be aware of the potential biases due to canopy morphology. Many crops have morphological features present at the top of the canopy and a bias may be introduced into canopy temperature based methods. A further complication may occur due to the anisotropy of canopy temperatures when the canopy is viewed from different angles. These differences can be as large as 3 to $5^{\circ} \mathrm{C}$, introducing another source of variation into canopy temperature observations particularly when measurements are taken at acute angles (Paw U et al., 1989).

Onset of water stress has been detected through observations of the variation of canopy temperatures within a field. Heermann and Duke (1978) found that when the foliage temperature was $1.5^{\circ} \mathrm{C}$ above air temperature irrigation of maize was needed, which formed a reliable index to determine irrigation timing. Hatfield et al. (1984c) evaluated canopy temperature variability patterns in grain sorghum and found that when the standard deviation of canopy temperature was less than $0.7^{\circ} \mathrm{C}$, less than $50 \%$ of available soil water was removed from the upper $1.5-\mathrm{m}$ profile. The variance of canopy temperature increased linearly when soil water extraction increased above $50 \%$ of the available soil water. Bryant and Moran (1999) adopted a slightly different method based on the histogram of canopy temperatures using the mean and standard deviation. They found that recently irrigated fields had histograms with 
a normal distribution whereas stressed fields deviate from this pattern. The variability techniques have potential for aircraft and high resolution satellite data as management tools.

One valuable application of canopy or surface temperature is the direct inclusion of these temperatures into energy balance models to estimate evapotranspiration (ET). Evapotranspiration estimates provide a sound approach for measuring crop water requirements (Hatfield et al., 1984b). Zhang et al. (1995) showed the remote sensing model closely compared to area ET averages obtained from ground-based stations. Evapotranspiration is one of the critical energy balance components utilized in crop growth models and estimation of ET over large areas would help in crop yield estimation. In crop water use models, crop coefficients are required inputs that can be obtained from remotely sensed observations of reflectance related to canopy development (Bausch and Neale, 1989). This application uses a VI to derive a crop coefficient; however, this method couples standard meteorological data with more infrequent observations of the canopy to complement the remote sensing observations.

One of the major problems encountered when using singlesource models occurs when there is a partial canopy-covered surface (Kustas et al., 1989; Hall et al., 1992; Vining and Blad, 1992). Single-source approaches treat the soil-canopy system as a single layer or source of energy exchange. A single-source model cannot accommodate the differences in atmospheric coupling associated with the soil or canopy components of the scene (Norman and Becker, 1995). Two-source approaches, which consider separately the flux contributions from the soil and canopy components, improve the ability to estimate fluxes over a wide range of vegetation cover conditions (e.g., Norman et al., 1995, 2000; Kustas and Norman, 1999). Use of canopy or surface temperatures as direct inputs into large-scale ET models provides a spatial representation of water use that is not possible with single energy balance systems. Refinement of regional scale models using remote sensing requires an integration of several remote sensing and ground-based observations. Anderson et al. (2004) showed that canopy biophysical properties, for example, LAI, canopy height, and vegetation water content, could be obtained from NDWI and OSAVI indices over regional scale studies with an accuracy in LAI of 0.6 and canopy height of 0.2 $\mathrm{m}$. One of the problems of these observations is that the vegetation is not distributed uniformly and the nonrandom effects of vegetative cover on the regional scale energy exchanges have been addressed through an approach using a scaling method called DisALEXI (Disaggregation Atmosphere-Land Exchange Inverse) that disaggregates $5-\mathrm{km}$ regional output to the Landsat TM resolution (Anderson et al., 2005). Anderson et al. (2007) developed a multiscale approach that uses thermal, visible, and near-infrared imagery from multiple satellites to partition the fluxes between the soil and canopy. They developed an approach with the ability to map fluxes at a range of scales from $1 \mathrm{~m}$ to 10 $\mathrm{km}$ that has the potential of being able to assess the representativeness of sensor placement across complex landscapes. The evolution of this type of method shows the further refinement in the ability to use remote sensing as an assessment tool for ground-based observations as well as a method for regional scale measurements.

\section{METHODS FOR EMPLOYING REMOTE SENSING}

Methods for remote sensing of agronomic parameters include: (i) empirical (parametric statistic) correlations between surface-measured parameters and VIs, (ii) inversion of the agronomic parameter from physically based canopy reflectance models, and (iii) estimation using a neural network (NN). The results from these methods vary by scale of observation, type of vegetation, spectral bands, and the sophistication of the models. Each procedure requires optimization for a specific geographic location, the vegetation type, and the illumination conditions for the time of data acquisition.

The simplest approach uses a regression equation between the VI and the parameter of interest calibrated with in situ measurements of the parameter. The number and location of the calibration samples can affect the performance of the procedure.

Each approach has its disadvantages. Parameter retrieval using empirical approaches tend to be time and space-specific. Empirical relationships are valid only under conditions similar to those at the time the correlation was established. The relationship may break down if the solar and viewing geometries, soil background, Chl concentrations, canopy architecture, or moisture conditions are different, and in situ calibration measurements over large areas are impractical (Jacquemoud et al., 1995).

Retrieval of parameters through numerical inversion of physically based canopy reflectance models is computationally intensive when applied to each sensor reading (typically a pixel). There is no universally applicable canopy reflectance model for all vegetation types, and thus model selection is often a compromise between model complexity, invertability, and computational efficiency (Goel, 1989; Jacquemoud and Baret, 1990; Jacquemoud et al., 1995). One-dimensional radiative transfer models have been shown to work well for inversion despite the tendency to oversimplify. The Scattering by Arbitrarily Inclined Leaves (SAIL; Verhoef, 1984) model has been used for inversion of LAI (a user-friendly version can be found at http://ars. usda.gov/services/software/download.htm?softwareid=12\&m odecode=12-65-06-00; verified 22 Jan. 2008). Problems with inversions include lack of convergence, sensitivity of results to initializing values, and difficulty estimating model input parameters that are challenging to obtain or cannot be directly measured.

Neural network approaches have not been generalized to handle all wavelength and viewing condition combinations (Fang and Liang, 2003; Kimes et al., 1998). Observations that are used to train the NN must encompass the expected range of values for the area of interest. The availability of a large, surfacemeasured, high quality, vegetation data set is therefore necessary for the validation of the NN approach over large areas. An advantage of the NN approach is that it allows the use of complex, detailed models otherwise cumbersome for traditional inversion because of slow computational times (Jacquemoud et al., 1995). Further, NN approaches are not as affected by initial choices as traditional model inversion approaches are, nor are they as computationally intensive as traditional techniques. Forward runs of the NN are fast once NN training is completed. Other variations of these approaches include withinscene scaling of an SVI that yields LAI directly as a function of the fraction of vegetation cover (Choudhury et al., 1994; 
Campbell and Norman, 1998) and a hybrid radiative transferneural network (RT-NN) approach (Fang and Liang, 2003). Both the scaled NDVI and the hybrid method offer the advantages of requiring little or no in situ calibration measurements.

Plots of estimated vs. measured LAI appear to suggest that the calibrated methods, such as regression, better estimate the full range of LAI values while the uncalibrated methods such as the scaled NDVI and the hybrid RT-NN method perform reasonably well for midrange LAI values and show less consistent estimation of higher and lower LAI values. While not performing as well as the SVI approaches, the hybrid RT-NN results are still impressive, given that site-specific data for calibration are not required (Walthall et al., 2004).

An application of remote sensing for current agronomic problems is the use of VIs simulated from plant growth models and then compared with remotely sensed observations as detailed by Ko et al. (2006). This type of approach provides a framework for using remotes sensing as either a calibration tool for plant growth models or as a direct input.

\section{CHALLENGES}

The major challenge for remote sensing researchers is to fully realize the potential of remote sensing as a source of useful information that can be used for agronomic management decisions. This requires an expansion of our knowledge base of the agronomic information content of remote sensing data, and algorithmic innovations for exploiting such data. We offer the following suggestions and perspectives for future research directions:

- There is a need to expand our understanding of the information content of remotely sensed data. As previously stated, SWIR, TIR, and microwave regions are especially attractive as topics for new investigations. The requirement that both leaf-level information and canopy-level information content be addressed is paramount to developing a more complete realization of the potential of these wavelengths.

- There is a need to refine agronomic information retrieval algorithms so that they can be extended through space (within fields, across landscapes and regions, at different geographic locales, under differing climates, etc.) and time (at different times within a growing season, among growing seasons, at different times of the day, etc.). Currently, when conducting agronomic parameter retrieval, stratification of the landscape by crop type is often used, thus suggesting that some algorithms may require optimization of spectral bands for specific crops.

- There is a need to quantify the error bars associated with agronomic parameter retrieval using remote sensing. An understanding of the error associated with remote sensingbased retrieval of agronomic information will better define optimal conditions for its use. Part of this challenge is the need to better understand what is needed for extension of remote sensing methods beyond the structured environment of research studies to the unstructured environment of fieldscale operations. The uncertainty of remote sensing relationships must be quantified in a way so that the information can be used with confidence at a scale and location beyond that of the original study.
- There is a need to simplify algorithms used for remote sensing of agronomic parameter retrieval using remote sensing. Turn-key solutions with an appropriate degree of automated calibration and processing to compensate for different crops, and the variability imposed by time and space, suitable for use by specialists and nonspecialists, are needed.

Paths to addressing these challenges vary. The past $40 \mathrm{yr}$ of VI development illustrated by Table 2 is evidence of a highly successful evolutionary approach. Expansion of the types of agronomic information that can be retrieved from remote sensing, and refinement of the spectral bands required for retrieving specific information have evolved into hyperspectral remote sensing. For many applications, VIs have been developed as surrogates for agronomic properties that are closely aligned with what we observe with the human eye. As research progressed, VIs has gone far beyond just extending what is possible with the human eye, suggesting that retrieval of "nonvisual" agronomic information is possible given the right combination of spectral bands and analysis methods. Attention to unwanted signals (i.e., "noise") from variations of underlying soil reflectance, plant canopy architecture, illumination conditions, viewing conditions, and contributions from the sensor systems and platforms have also refined VIs and fostered insights to the limitations of using remote sensing.

Observed reflectance or emittance signals from a canopy are a function of the leaf spectral and morphological properties, the variation of leaf cover over the soil, the architectural arrangement of the leaves, branches and stems, percentage vegetative cover, and the atmospheric signals between the surface and the sensor. For the VIs of Table 2, topography, soil roughness, canopy architecture, and row have been treated as unwanted noise in the observations. A revolutionary path of remote sensing research is also needed that will exploit the potentially useful information available from these sources of noise. One approach is to investigate pattern recognition technologies that will enable quantification of row structure, leaf angle, or foliage distribution, which can be related to stress, genotype identification, weed identification, disease presence, or insect damage. Multiple view angle (i.e., BRDF) approaches are an example of how exploitation of a traditional source of noise in imagery have been investigated as a new source of information. It may thus be possible to provide new and perhaps better information about crop canopies when information from these traditional sources of noise can be added to spectral VI analysis.

Most of the emerging technologies being developed place remote sensing tools directly into the hands of producers use active sensors rather than passive systems. There are a growing number of sensors that can be mounted directly onto implements for sensing the crop or soil for the detection of $\mathrm{N}$ or weeds in fields and linked to control units for directing fertilizer or pesticide applications. This approach helps overcome limitations of timeliness, reliability, turn-around time, weather uncertainties, and cost. New inexpensive sensors using specific wavelengths have been shown to be sensitive to desired plant attributes and functions (i.e., color, biomass, water stress, fluorescence, etc.). As noted by Holland et al. (2006), scientists have been developing ingenious ways to study plants and automate management practices for many years. The uncertainty facing 
producers is knowing which input or plant growth factor(s) is limiting biomass production and the risk that a slight or modest temporary stress or deficiency might have on yield and profitability. Using remote sensing data to help make agronomic decisions provides a tool to improve field-scale management. Improving our understanding of the variation in remote sensing observations will help quantify the uncertainty and improve our confidence in this information source.

\section{REFERENCES}

Adams, M.L., W.D. Philpot, and W.A. Norvell. 1999. Yellowness index: An application of spectral second derivatives to estimate chlorosis of leaves in stressed vegetation. Int. J. Remote Sens. 20:3663-3675.

Allen, W.A., H.W. Gausman, and A.J. Richardson. 1973. WillstatterStoll theory of leaf reflectance evaluated by ray tracing. Appl. Opt. 12:2448-2453.

Allen, W.A., H.W. Gausman, A.J. Richardson, and J.R. Thomas. 1969. Interaction of isotropic light with a compact plant leaf. J. Opt. Soc. Am. 59:1376-1379.

Anderson, J., M. Norman, W.P. Kustas, F. Li, J.H. Prueger, and J.R. Mecikalski. 2005. Effects of vegetation clumping on two-source model estimates of surface energy fluxes from an agricultural landscape during SMACEX. J. Hydrometeorol. 6:892-909.

Anderson, M.C., W.P. Kustas, and J.M. Norman. 2007. Upscaling flux observations from local to continental scales using thermal remote sensing. Agron. J. 99:240-254.

Anderson, M.C., C.H.U. Neale, F. Li, J.M. Norman, W.P. Kustas, H. Jayanthi, and J. Chavez. 2004. Upscaling ground observations of vegetation water content, canopy height, and leaf area index during SMEX02 using aircraft and Landsat imagery. Remote Sens. Environ. 92:447-464.

Baret, F., G. Guyot, and D.J. Major. 1989. TSAVI: A vegetation index which minimizes soil brightness effects on LAI and APAR estimation. Proc. IGARRS 0/12th Canadian Symposium on Remote Sensing, Vancouver, Canada. Vol. 3:1355-1358.

Barnes, E.M., K.A. Sudduth, J.W. Hummel, S.M. Leach, D.L. Corwin, C. Yeng, C.S.T. Daughtry, and W.C. Bausch. 2003. Remote- and groundbased sensor techniques to map soil properties. Photogramm. Eng. Remote Sens. 69:619-630.

Bauer, M.E., C.S.T. Daughtry, L.L. Biehl, E.T. Kanemasu, and F.G. Hall. 1986. Field spectroscopy of agricultural crops. IEEE Trans. Geosci. Remote Sens. GE-24(1):65-75.

Bausch, W.C., and K. Diker. 2001. Innovative remote sensing techniques to increase nitrogen use efficiency of corn. Commun. Soil Sci. Plant Anal. 32:1371-1390.

Bausch, W.C., and H.R. Duke. 1996. Remote sensing of plant nitrogen status in corn. Trans. ASAE 32:1869-1875.

Bausch, W.C., and C.M.U. Neale. 1989. Spectral inputs improve corn crop coefficients and irrigation scheduling. Trans. ASAE 32:1901-1908.

Birth, G.S., and G. McVey. 1968. Measuring the color of growing turf with a reflectance spectrophotometer. Agron. J. 60:640-643.

Blackburn, G.A. 1998. Quantifying chlorophylls and carotenoids at leaf and canopy scales: An evaluation of some hyperspectral approaches. Remote Sens. Environ. 66:273-285.

Blackmer, T.M., and J.S. Schepers. 1996. Aerial photography to detect nitrogen stress in corn. J. Plant Physiol. 148:440-444.

Blackmer, T.M., J.S. Schepers, and G.E. Varvel. 1994. Light reflectance compared with other nitrogen stress measurements in corn leaves. Agron. J. 86:934-938.

Blackmer, T.M., J.S. Schepers, G.E. Varvel, and G.E. Meyer. 1996a. Analysis of aerial photography for nitrogen stress within corn fields. Agron. J. 88:729-733.

Blackmer, T.M., J.S. Schepers, G.E. Varvel, and E.A. Walter-Shea. 1996b. Nitrogen deficiency detection using reflected shortwave radiation from irrigated corn canopies. Agron. J. 88:1-5.

Blackmer, T.M., J.S. Schepers, and M.F. Vigil. 1993. Chlorophyll meter readings in corn as affected by plant spacing. Commun. Soil Sci. Plant Anal. 24:2507-2516.

Bryant, R.B., and M.S. Moran. 1999. Determining crop water stress from crop temperature variability. p. 289-296. In Proc. Int Airborne Remote
Sensing Conf., Ottawa, ON, Canada. 21-24 June 1999. Canadian Remote Sensing Society, Kanata, ON

Buschmann, C., and E. Nagel. 1993. In vivo spectroscopy and internal optics of leaves as basis for remote sensing of vegetation. Int. J. Remote Sens. 14:711-722.

Campbell, G.S., and J.M. Norman. 1998. An Introduction to environmental physics. Springer-Verlag, New York.

Campbell, P.K.E., E.M. Middleton, J.E. McMurtry, L.A. Corp, and E.W. Chappelle. 2007. Assessment of vegetation stress using reflectance or fluorescence measurements. J. Environ. Qual. 36:832-845.

Carlson, T.N., R.R. Gillies, and E.M. Perry. 1994. A method to make use of thermal infrared temperature and NDVI measurements to infer surface soil water content and fractional vegetation cover. Remote Sens. Rev. 9:161-173.

Carter, G.A. 1994. Ratios of leaf reflectances in narrow wavebands as indicators of plant stress. Int. J. Remote Sens. 15:697-703.

Carter, G.A., and A.K. Knapp. 2001. Leaf optical properties in higher plants: Linking spectral characteristics to stress and chlorophyll concentration. Am. J. Bot. 84:677-684.

Chalker-Scott, L. 1999. Environmental significance of anthocyanins in plant stress-responses. Photochem. Photobiol. 70:1-9.

Chappelle, E.W., M.S. Kim, and J.E. McMurtrey, III. 1992. Ratio analysis of reflectance spectra (RARS): An algorithm for the remote estimation of the concentrations of chlorophyll a, chlorophyll b, and carotenoids in soybean leaves. Remote Sens. Environ. 39:239-247.

Choudhury, B.J., N.U. Ahmed, S.B. Idso, R.J. Reginato, and C.S.T. Daughtry. 1994. Relations between evaporation coefficients and vegetation indices studied by model simulations. Remote Sens. Environ. 5:1-17.

Cui, M., T.C. Vogelmann, and W.K. Smith. 1991. Chlorophyll and light gradients in sun and shade leaves of Spinacia oleraceae. Plant Cell Environ. 14:493-500.

Curran, P.J., J.L. Dungan, and H.L. Gholz. 1990. Exploring the relationship between reflectance red edge and chlorophyll content in slash pine. Tree Physiol. 7:33-48.

Datt, B. 1998. Remote sensing of chlorophyll a, chlorophyll b, chlorophyll $\mathrm{a}+\mathrm{b}$, and total carotenoid content in eucalyptus leaves. Remote Sens. Environ. 66:111-121.

Daughtry, C.S.T., C.L. Walthall, M.S. Kim, E. Brown de Colstoun, and J.E. McMurtrey, III. 2000. Estimating corn leaf chlorophyll content from leaf and canopy reflectance. Remote Sens. Environ. 74:229-239.

Deering, D.W. 1978. Rangeland reflectance characteristics measured by aircraft and spacecraft sensors. Ph.D. diss. Texas A\&M Univ., College Station.

Demmig-Adams, B., A.M. Gilmore, and W.W. Adams, III. 1996. In vivo functions of carotenoids in higher plants. FASEB J. 10:403-412.

DeTar, W.R., J.V. Penner, and H.A. Funk. 2006. Airborne remote sensing to detect plant water stress in full canopy cotton. Trans. ASAE 49:655665.

Doraiswamy, P.C., J.L. Hatfield, T.J. Jackson, B. Akhmedov, J. Prueger, and A. Stern. 2004. Crop condition and yield simulations using Landsat and MODIS. Remote Sens. Environ. 92:548-559.

Ehler, W.L., S.B. Idso, R.D. Jackson, and R.J. Reginato. 1978. Wheat canopy temperatures: Relation to plant water potential. Agron. J. 70:251-256.

Fang, H., and S. Liang. 2003. Retrieving leaf area index with a neural network method: Simulation and validation. IEEE Trans. Geosci. Remote Sens. 41:2052-2062.

Feldhake, C.M., and W.M. Edwards. 1992. Pasture canopy temperature under cloudy humid conditions. Agric. For. Meteorol. 60:133-144.

Filella, I., I. Serrano, J. Serra, and J. Penuelas. 1995. Evaluating wheat nitrogen status with canopy reflectance indices and discriminant analysis. Crop Sci. 35:1400-1405.

Fukshansky, L.A., A.M. Remisowsky, J. McClendon, A. Ritterbusch, T. Richter, and H. Mohr. 1993. Absorption spectra of leaves corrected for scattering and distributional error: A radiative transfer and absorption statistics treatment. Photochem. Photobiol. 57:538-555.

Gamon, J.A., J. Penuelas, and C.B. Field. 1992. A narrow-waveband spectral index that tracks diurnal changes in photosynthetic efficiency. Remote Sens. Environ. 41:35-44.

Gamon, J.A., and J.S. Surfus. 1999. Assessing leaf pigment content and activity with a reflectometer. New Phytol. 143:105-117.

Gardner, B.R., D.C. Nielsen, and C.C. Shock. 1992a. Infrared thermometry 
Hatfield, Gitelson, Schepers \& Walthall in Agronomy Journal (2008) 100: S-117-S-131. DOI: 10.2134/agronj2006.0370c.

and the Crop Water Stress Index: I. History, theory, and baselines. J. Prod. Agric. 5:462-466.

Gardner, B.R., D.C. Nielsen, and C.C. Shock. 1992b. Infrared thermometry and the Crop Water Stress Index: II. Sampling procedures and interpretation. J. Prod. Agric. 5:466-475.

Gates, D.M., H.J. Keegan, J.C. Schleter, and V.R. Weidner. 1965. Spectral properties of plants. Appl. Opt. 4:11-20.

Gausman, H.W. 1973. Reflectance, transmittance, and absorptance of light by subcellular particles of spinach (Spinacia oleracea L.) leaves. Agron. J. 65:551-553.

Gausman, H.W. 1974. Leaf reflectance of near-infrared. Photogramm. Eng. Remote Sens. 40:183-191.

Gausman, H.W. 1977. Reflectance of leaf components. Remote Sens. Environ. 6:1-9.

Gausman, H.W. 1984. Evaluation of factors causing reflectance differences between sun and shade leaves. Remote Sens. Environ. 15:177-181.

Gausman, H.W., and W.A. Allen. 1973. Optical parameters of leaves of 30 plant species. Plant Physiol. 52:57-62.

Gausman, H.W., W.A. Allen, and R. Cardenas. 1969a. Reflectance of cotton leaves and their structure. Remote Sens. Environ. 1:19-22.

Gausman, H.W., W.A. Allen, R. Cardenas, and A.J. Richardson. 1971. Effects of leaf nodal position on absorption and scattering coefficients and infinite reflectance of cotton leaves, Gossypium hirsutum L. Agron. J. 63:87-91.

Gausman, H.W., W.A. Allen, and D.E. Escobar. 1974. Refractive-index of plant-cell walls. Appl. Opt. 13:109-111.

Gausman, H.W., W.A. Allen, V.I. Myers, and R. Cardenas. 1969b. Reflectance and internal structure of cotton leaves, Gossypium hirsutum L. Agron. J. 61:374-376.

Gausman, H.W., D.E. Escobar, R.R. Rodriguez, C.E. Thomas, and R.L. Bowen. 1978. Ozone damage detection in cantaloupe plants. Photogramm. Eng. Remote Sens. 44:481-485.

Gausman, H.W., A.H. Gerbermann, and C.L. Wiegand. 1975a. Use of ERTS-1 data to detect chlorotic grain-sorghum. Photogramm. Eng. Remote Sens. 41:177-179.

Gausman, H.W., A.H. Gerbermann, C.L. Wiegand, R.W. Leamer, R.R. Rodriguez, and J.R. Noriega. 1975b. Reflectance differences between crop residues and bare soils. Soil Sci. Soc. Am. J. 39:752-755.

Gausman, H.W., and W.G. Hart. 1974. Reflectance of sooty mold fungus on citrus leaves over 2.5 to 40 -micrometer wavelength interval. J. Econ. Entomol. 67:479-480.

Gausman, H.W., R.M. Menges, A.J. Richardson, H. Walter, R.R. Rodriguez, and S. Tamez. 1981. Optical-parameters of leaves of 7 weed species. Weed Sci. 29:24-26.

Gausman, H.W., R.R. Rodriguez, and A.J. Richardson. 1976. Infinite reflectance of dead compared with live vegetation. Agron. J. 68:295296.

Gitelson, A.A. 2004. Wide Dynamic Range Vegetation Index for remote quantification of crop biophysical characteristics. J. Plant Physiol. 161:165-173.

Gitelson, A.A., and M.N. Merzlyak. 1994. Quantitative estimation of chlorophyll-a using reflectance spectra: Experiments with autumn chestnut and maple leaves. J. Photochem. Photobiol. 22:247-252.

Gitelson, A., and M.N. Merzlyak. 1996. Signature analysis of leaf reflectance spectra: Algorithm development for remote sensing of chlorophyll. J. Plant Physiol. 148:494-500.

Gitelson, A.A., Y.J. Kaufman, and M.N. Merzlyak. 1996a. Use of a green channel in remote sensing of global vegetation from EOS-MODIS. Remote Sens. Environ. 58:289-298.

Gitelson, A., M. Merzlyak, and H. Lichtenthaler. 1996b. Detection of red edge position and chlorophyll content by reflectance measurements near 700 nm. J. Plant Physiol. 148:501-508.

Gitelson, A.A., C. Buschmann, and H.K. Lichtenthaler. 1999. The Chlorophyll Fluorescence Ratio F735/F700 as an accurate measure of the chlorophyll content in plants. Remote Sens. Environ. 69:296302.

Gitelson, A.A., M.N. Merzlyak, and O.B. Chivkunova. 2001. Optical properties and non-destructive estimation of anthocyanin content in plant leaves. Photochem. Photobiol. 74:38-45.

Gitelson, A.A., Y. Zur, O.B. Chivkunova, and M.N. Merzlyak. 2002a. Assessing carotenoid content in plant leaves with reflectance spectroscopy. Photochem. Photobiol. 75:272-281.
Gitelson, A.A., Y.J. Kaufman, R. Stark, and D. Rundquist. 2002b. Novel algorithms for remote estimation of vegetation fraction. Remote Sens. Environ. 80:76-87.

Gitelson, A.A., U. Gritz, and M.N. Merzlyak. 2003a. Relationships between leaf chlorophyll content and spectral reflectance and algorithms for non-destructive chlorophyll assessment in higher plant leaves. J. Plant Physiol. 160:271-282.

Gitelson, A.A., A. Viña, T.J. Arkebauer, D.C. Rundquist, G. Keydan, and B. Leavitt. 2003b. Remote estimation of leaf area index and green leaf biomass in maize canopies. Geophys. Res. Lett. 30(5):1248 doi:10.1029/2002Gl016450.

Gitelson, A.A., S.B. Verma, A. Viña, D.C. Rundquist, G. Keydan, B. Leavitt, T.J. Arkebauer, G.G. Burba, and A.E. Suyker. 2003c. Novel technique for remote estimation of $\mathrm{CO}_{2}$ flux in maize. Geophys. Res. Lett. 30(9):1486 doi:10.1029/2002G1016543.

Gitelson, A.A., A. Vińa, D.C. Rundquist, V. Ciganda, and T.J. Arkebauer. 2005. Remote estimation of canopy chlorophyll content in crops. Geophys. Res. Lett. 32:108403 doi:10.1029/2005Gl022688.

Gitelson, A.A., G.P. Keydan, and M.N. Merzlyak. 2006a. Three-band model for noninvasive estimation of chlorophyll, carotenoids, and anthocyanin contents in higher plant leaves. Geophys. Res. Lett. 33:111402 doi:10.1029/2006Gl026457.

Gitelson, A.A., A. Viña, S.B. Verma, D.C. Rundquist, T.J. Arkebauer, G. Keydan, B. Leavitt, V. Ciganda, G.G. Burba, and A.E. Suyker. 2006b. Relationship between gross primary production and chlorophyll content in crops: Implications for the synoptic monitoring of vegetation productivity. J. Geophys. Res. 111, D08S11, doi:10.1029/ 2005JD006017.

Goel, N.S. 1988. Models of vegetation canopy reflectance and their use in estimation of biophysical parameters from reflectance data. Remote Sens. Rev. 4:1-222.

Goel, N.S. 1989. Inversion of canopy reflectance models for estimation of biophysical parameters from reflectance data. In G. Asrar (ed.) Theory and applications of optical remote sensing. John Wiley \& Sons, New York.

Hall, F.G., K.F. Huemmrich, S.J. Goetz, P.J. Sellers, and J.E. Nickeson. 1992. Satellite remote sensing of surface energy balance: Success, failures, and unresolved issues in FIFE. J. Geophys. Res. 97(D17):19061-19089.

Hatfield, J.L. 1983. Remote sensing estimators of potential and actual crop yield. Remote Sens. Environ. 13:301-311.

Hatfield, J.L., J.E. Quisenberry, and R.E. Dilbeck. 1987. Use of canopy temperatures to identify water conservation in cotton germplasm. Crop Sci. 27:269-273.

Hatfield, J.L., G. Asrar, and E.T. Kanemasu. 1984a. Intercepted photosynthetically active radiation estimated by spectral reflectance. Remote Sens. Environ. 14:65-75.

Hatfield, J.L., R.J. Reginato, and S.B. Idso. 1984b. Evaluation of canopy temperature-evapotranspiration models over various crops. Agric. For. Meteorol. 32:41-53.

Hatfield, J.L., M. Vauchlin, S.R. Vieira, and R. Bernard. 1984c. Surface temperature variability patterns within irrigated fields. Agric. Water Manage. 8:429-437.

Hatfield, J.L., P.J. Pinter, Jr., E. Chasseray, C.E. Ezra, R.J. Reginato, S.B. Idso, and R.D. Jackson. 1984d. Effects of panicles on infrared thermometer measurements of canopy temperature in wheat. Agric. For. Meteorol. 32:97-105.

Hatfield, J.L., J.H. Prueger, and W.P. Kustas. 2004. Remote sensing of dryland crops. p. 531-568. In S.L. Ustin (ed.) Remote sensing for natural resource management and environmental monitoring: Manual of remote sensing. 3rd ed. John Wiley, Hoboken, NJ.

Heath, O.V.S. 1969. The physiological aspects of photosynthesis. Stanford Univ. Press, Stanford, CA.

Heermann, D.F., and H.R. Duke. 1978. Evaluation of crop water stress u nder limited irrigation. ASAE Pap. 78-2556. ASAE, St. Joseph, MI.

Heilman, J.L., W.E. Heilman, and D.G. Moore. 1981. Remote sensing of canopy temperature at incomplete cover. Agron. J. 73:403-406.

Hendry, G.A.F., J.D. Houghton, and S.B. Brown. 1987. The degradation of chlorophyll-a biological enigma. New Phytol. 107:255-302.

Holland, K.H., J.S. Schepers, and J.F. Shanahan. 2006. Configurable multispectral active sensor for high-speed plant canopy assessment. In D.J. Mulla (ed.) Proc. 8th Int. Conf. on Precision Agriculture [CD]. Univ. of Minnesota, Minneapolis.

Huete, A.R. 1988. A soil-adjusted vegetative index (SAVI). Remote Sens. 
Environ. 25:295-309.

Huete, A.R., H.Q. Liu, K. Batchily, and W. van Leeuwen. 1997. A comparison of vegetation indices over a global set of TM images for EOS-MODIS. Remote Sens. Environ. 59:440-451.

Huete, A., K. Didan, T. Miura, E.P. Rodriguez, X. Gao, and L.G. Ferreira. 2002. Overview of the radiometric and biophysical performance of the MODIS vegetation indices. Remote Sens. Environ. 83:195-213.

Hunt, E.R., J.H. Everitt, J.C. Ritchie, M.S. Moran, D.T. Booth, G.L. Anderson, P.E. Clairk, and M.S. Seyfried. 2003. Applications and research using remote sensing for rangeland management. Photogramm. Eng. Remote Sens. 69:675-693.

Idso, S.B., R.D. Jackson, and R.J. Reginato. 1977. Remote sensing of crop yields. Science 196:19-25.

Idso, S.B., R.D. Jackson, P.J. Pinter, Jr., R.J. Reginato, and J.L. Hatfield. 1981. Normalizing the stress-degree-day parameter for environmental variability. Agric. For. Meteorol. 24:45-55.

Jackson, R.D. 1983. Spectral indices in N-space. Remote Sens. Environ. 13:409-421.

Jacquemoud, S., and F. Baret. 1990. PROSPECT: A model of leaf optical properties spectra. Remote Sens. Environ. 34:75-91.

Jacquemoud, S., F. Baret, B. Andrieu, F.M. Danson, and K. Jaggard. 1995 Extraction of vegetation biophysical parameters by inversion of the PROSPECT+SAIL models on sugar beet canopy reflectance data: Application to TM and AVIRIS sensors. Remote Sens. Environ. 52:163-172.

Jackson, R.D., and A.R. Huete. 1991. Interpreting vegetation indices. Prev. Vet. Med. 11:185-200.

Jackson, R.D., R.J. Reginato, and S.B. Idso. 1977. Wheat canopy temperatures: A practical tool for evaluating water requirements. Water Resour. Res. 13:651-656.

Jackson, R.D., S.B. Idso, R.J. Reginato, and P.J. Pinter, Jr. 1981. Canopy temperature as a crop water stress indicator. Water Resour. Res. 17:1133-1138

Jackson, T.J., and T.J. Schmugge. 1989. Passive microwave remote sensing system for soil moisture: Some supporting research. IEEE Trans. Geosci. Remote Sens. 27:225-235.

Jackson, T.J., D.M. LeVine, A.Y. Hsu, A. Oldak, P.J. Starks, C.T. Swift, J. Isham, and M. Hakan. 1999. Soil moisture mapping at regional scales using microwave radiometry: The southern Great Plains hydrology experiment. IEEE Trans. Geosci. Remote Sens. 37:2136-2151.

Jackson, T.J., D. Chen, M. Cosh, F. Li, M. Anderson, C. Walthall, P. Doraiswamy, and E.R. Hunt. 2004. Vegetation water content mapping using Landsat data derived normalized difference water index for corn and soybeans. Remote Sens. Environ. 92:475-482.

Jordan, C.F. 1969. Derivation of leaf area index from quality of light on the forest floor. Ecology 50:663-666.

Kaufman, Y., and D. Tanré. 1992. Atmospherically resistant vegetation index (ARVI) for EOS-MODIS. IEEE Trans. Geosci. Remote Sens. 30:261-270.

Kauth, R.J., and G.S. Thomas. 1976. The tasseled cap-A graphic description of the spectral-temporal development of agricultural crops as seen by Landsat. p. 41-51. In Proc. Symp. on Machine Processing of Remotely Sensed Data. Purdue Univ., West Lafayette, IN.

Ko, J., S.J. Maas, S. Mauget, G. Piccinni, and D. Wanjura. 2006. Modeling water-stressed cotton growth using within-season remote sensing data. Agron. J. 98:1600-1609.

Kimes, D.S., R.F. Nelson, M.T. Manry, and A.K. Fung. 1998. Attributes of neural networks for extracting continuous vegetation variables from optical and radar measurements. Int. J. Remote Sens. 19:2639-2663.

Kumar, R., and L. Silva. 1973. Light ray tracing through a leaf cross section. Appl. Opt. 12:2950-2954.

Kustas, W.P., and J.M. Norman. 1999. Evaluation of soil and vegetation heat flux predictions using a simple two-source model with radiometric temperatures for a partial canopy cover. Agric. For. Meteorol. 94:1329.

Kustas, W.P., B.J. Choudhury, and M.S. Moran. 1989. Determination of sensible heat flux over sparse canopy using thermal infrared data. Agric. For. Meteorol. 44:197-216.

Kustas, W.P., A.N. French, J.L. Hatfield, T.J. Jackson, M.S. Moran, A. Rango, J.C. Ritchie, and T.J. Schmugge. 2003. Remote sensing research in hydrometeorology. Photogram. Eng. Remote Sens. 69:631-646.

Le Maire, G., C. Francois, and E. Dufrene. 2004. Towards universal broad leaf chlorophyll indices using PROSPECT simulated database and hyperspectral reflectance measurements. Remote Sens. Environ. 89:128.

LaVine, D.M., A. Griffis, C.T. Swift, and T.J. Jackson. 1994. ESTAR: A synthetic microwave radiometer for remote sensing applications. Proc. IEEE 82:1787-1801.

Liang, S. 2004. Quantitative remote sensing of land surfaces. Wiley, Hoboken, NJ.

Liang, S., and A.S. Strahler (ed.). 2000. Land surface bidirectional reflectance distribution function (BRDF): Recent advances and future prospects. Remote Sens. Rev. 18:2-4.

Lichtenthaler, H.K. 1987. Chlorophyll and carotenoids: Pigments of photosynthetic biomembranes. Meth. Enzym. 148:331-382.

Lichtenthaler, H.K., A.A. Gitelson, and M. Lang. 1996. Non-destructive determination of chlorophyll content of leaves of a green and an aurea mutant of tobacco by reflectance measurements. J. Plant Physiol. 148:483-493.

Markwell, J., J.C. Osterman, and J.L. Mitchell. 1995. Calibration of the Minolta SPAD-502 leaf chlorophyll meter. Photosynth. Res. 46:467472.

Mariotti, M., L. Ercoli, and A. Masoni. 1996. Spectral properties of iron deficient corn and sunflower leaves. Remote Sens. Environ. 58:282288.

Merzlyak, M.N., and A.A. Gitelson. 1995. Why and what for the leaves are yellow in autumn? On the interpretation of optical spectra of senescing leaves (Acer platanoides L.). J. Plant Physiol. 145:315-320.

Merzlyak, M.N., A.A. Gitelson, O.B. Chivkunova, and V.Y. Rakitin. 1999. Non-destructive optical detection of leaf senescence and fruit ripening Physiol. Plant. 106:135-141.

Moran, J.A., A.K. Mitchell, G. Goodmanson, and K.A. Stockburger. 2000. Differentiation among effects of nitrogen fertilization treatments on conifer seedlings by foliar reflectance: A comparison of methods. Tree Physiol. 20:1113-1120.

Moran, M.S., T.R. Clarke, Y. Inoue, and A. Vidal. 1994. Estimating crop water deficit using the relation between surface-air temperature and spectral vegetation index. Remote Sens. Environ. 49:246-263.

Moran, S., G. Fitzgerald, A. Rango, C. Walthall, E. Barnes, W. Bausch, T. Clarke, C. Daughtry, J. Everitt, D. Escobar, J. Hatfield, K. Havstad, T. Jackson, N. Kitchen, W. Kustas, M. McGuire, P. Pinter, Jr., K. Sudduth, J. Schepers, T. Schmugge, P. Starks, and D. Upchurch. 2003. Sensor development and radiometric correction for agricultural applications. Photogram. Eng. Remote Sens. 69:705-718.

Moss, R.A., and W.E. Loomis. 1952. Absorption spectra of leaves: I. The visible spectrum. Plant Physiol. 27:370-391.

Norman, J.M., and F. Becker. 1995. Terminology in thermal infrared remote sensing of natural surfaces. Remote Sens. Rev. 12:159-173.

Norman, J.M., and J.M. Welles. 1983. Radiative transfer in an array of canopies. Agron. J. 75:481-488.

Norman, J.M., W.P. Kustas, and K.S. Humes. 1995. A two-source approach for estimating soil and vegetation energy fluxes from observations of directional radiometric surface temperature. Agric. For. Meteorol. 77:263-293.

Norman, J.M., J.M. Welles, and E.A. Walter. 1985. Contrasts among bidirectional reflectance of leaves, canopies and soils. IEEE Trans. Geosci. Remote Sens. GE-23(5):659-667.

Norman, J.M., W.P. Kustas, J.H. Prueger, and G.R. Diak. 2000. Surface flux estimation using radiometric temperature: A dual-temperaturedifference method to minimize measurement errors. Water Resour. Res. 36:2263-2274.

Osborne, S.L., J.S. Schepers, and M.R. Schlemmer. 2004. Detecting nitrogen and phosphorus stress in corn using multi-spectral imagery. Commun. Soil Sci. Plant Anal. 35:505-516.

Patel, N.R., A.N. Mehta, and A.M. Shekh. 2001. Canopy temperature and water stress quantification in rainfed pigeonpea (Cajanus cajan (L.) Millsp.). Agric. For. Meteorol. 109:223-232.

Paw U, K.T., S.L. Ustin, and C.A. Zhang. 1989. Anisotropy of thermal infrared exitance in sunflower canopies. Agric. Forest Meteorol. 48:45-58.

Peñuelas, J., and I. Filella. 1998. Visible and near-infrared reflectance techniques for diagnosing plant physiological status. Trends Plant Sci. 3:151-156.

Penuelas, J., F. Baret, and I. Filella. 1995. Semi-empirical indices to assess carotenoids/chlorophyll a ratio from leaf spectral reflectance. Photosynthetica 31:221-230. 
Hatfield, Gitelson, Schepers \& Walthall in Agronomy Journal (2008) 100: S-117-S-131. DOI: 10.2134/agronj2006.0370c.

Peynado, A., H.W. Gausman, D.E. Escobar, and R.R. Rodriguez. 1980. Detecting freeze damage to citrus leaves. HortScience 15:435.

Pinter, P.J., J.L. Hatfield, J.S. Schepers, E.M. Barnes, M.S. Moran, C.S. Daughtry, and D.R. Upchurch. 2003. Remote sensing for crop management. Photogram. Eng. Remote Sens. 69:647-664.

Raun, W.R., J.B. Solie, G.V. Johnson, M.L. Stone, E.V. Lukina, W.E. Thomason, and J.S. Schepers. 2001. In-season prediction of potential grain yield in winter wheat using canopy reflectance. Agron. J. 93:131138.

Redelfs, M.S., L.R. Stone, E.T. Kanemasu, and M.B. Kirkham. 1987. Greenness-leaf area index relationships for seven row crops. Agron. J. 79:254-259.

Richardson, A.J., and C.L. Wiegand. 1977. Distinguishing vegetation from soil background information. Photogram. Eng. Remote Sens. 43:1541-1552.

Richardson, A.D., S.P. Duigan, and G.P. Berlyn. 2002. An evaluation of noninvasive methods to estimate foliar chlorophyll content. New Phytol. 153:185-194.

Richardson, A.J., C.L. Wiegand, D.F. Wanjura, D. Dusek, and J.L. Steiner. 1992. Multisite analyses of spectral-biophysical data for sorghum. Remote Sens. Environ. 41:71-82.

Ritchie, J.C., P.V. Zimba, and J.H. Everitt. 2003. Remote sensing techniques to assess water quality. Photogram. Eng. Remote Sens. 69:695-704.

Rondeaux, G., M. Steven, and F. Baret. 1996. Optimization of soil-adjusted vegetation indices. Remote Sens. Environ. 55:95-107.

Russel, C.A., C.L. Walthall, J.R. Irons, and E.C. Brown de Colstoun. 1995. Comparison of airborne and surface spectral bidirectional reflectance factors, spectral hemispherical reflectance and vegetation indices. J. Geophys. Res. 100(D12):25509-25522.

Schepers, J.S., T.M. Blackmer, W.W. Wilhelm, and M. Resende. 1996. Transmittance and reflectance measurements of corn leaves from plants with different nitrogen and water supply. J. Plant Physiol. 148:523-529.

Schepers, J.S., D.D. Francis, M. Vigil, and F.E. Below. 1992. Comparison of corn leaf nitrogen concentration and chlorophyll meter readings. Commun. Soil Sci. Plant Anal. 23:2173-2187.

Sellers, P.J. 1987. Canopy reflectance, photosynthesis, and transpiration: II. The role of biophysics in the linearity of their dependence. Remote Sens. Environ. 21:143-183.

Serrano, L., I. Filella, and J. Penuelas. 2000. Remote sensing of biomass and yield of winter wheat under different nitrogen supplies. Crop Sci. 40:723-731.

Shanahan, J.F., J.S. Schepers, D.D. Francis, G.E. Varvel, W.W. Wilhelm, J.S. Tringe, M.R. Schlemmer, and D.J. Major. 2001. Use of remote sensing imagery to estimate corn grain yield. Agron. J. 93:583-589.

Shanahan, J.F., K. Holland, J.S. Schepers, D.D. Francis, M.R. Schlemmer, and R. Caldwell. 2003. Use of crop reflectance sensors to assess corn leaf chlorophyll content. p. 135-150. In Digital imaging and spectral techniques: Applications to precision agriculture and crop physiology. ASA Spec. Publ. 66. ASA, Madison, WI.

Sims, D.A., and J.A. Gamon. 2002. Relationship between leaf pigment content and spectral reflectance across a wide range species, leaf structures and development stages. Remote Sens. Environ. 81:337354.

Suits, G.W. 1972. The calculation of the directional reflectance of a vegetative canopy. Remote Sens. Environ. 2:117-125.

Tanner, C.B. 1963. Plant temperature. Agron. J. 55:210-211.

Thomas, J.R., and H.W. Gausman. 1977. Leaf reflectance vs. leaf chlorophyll and carotenoid concentrations for eight crops. Agron. J. 69:799-802.

Tucker, C.J. 1977. Asymptotic nature of grass canopy spectral reflectance. Appl. Opt. 16:1151-1156.

Tucker, C.J. 1979. Red and photographic infrared linear combinations for monitoring vegetation. Remote Sens. Environ. 8:127-150.

Verhoef, W. 1984. Light scattering by leaf layers with application to canopy reflectance modelling: The SAIL model. Remote Sens. Environ. 16:125-141.

Verma, S.B., P.J. Sellers, C.L. Walthall, F.G. Hall, J. Kim, and S.J. Goetz. 1992. Photosynthesis and stomatal conductance related to reflectance on the canopy scale. Remote Sens. Environ. 44:103-116.

Vining, R.C., and B.L. Blad. 1992. Estimation of sensible heat flux from remotely sensed canopy temperatures. J. Geophys. Res. 97(D17):1895118954.

Vogelmann, T.C. 1993. Plant tissue optics. Annu. Rev. Plant Physiol. Plant

\section{Mol. Biol. 44:231-251.}

Vogelmann, T.C., G. Martin, G. Chen, and D. Buttry. 1991. Fiber optic microprobes and measurement of the light microenvironment within plant tissues. Adv. Bot. Res. 18:231-270.

Walker, G.L., and J.L. Hatfield. 1979. Test of the stress-degree-day concept using multiple planting dates of red kidney beans. Agron. J. 71:967971.

Walthall, C., W. Dulaney, M. Anderson, J. Norman, H. Fang, and S. Liang. 2004. A comparison of empirical and neural network approaches for estimating corn and soybean leaf area index from Landsat ETM+ imagery. Remote Sens. Environ. 92:465-474.

Walthall, C.L., J.M. Norman, J.M. Welles, G. Campbell, and B.L. Blad. 1985. A simple equation to approximate the bidirectional reflectance from vegetative canopies and bare soil surfaces. Appl. Opt. 24:383387.

Wanjura, D.F., and D.R. Upchurch. 2000. Canopy temperature characterizations of corn and cotton water status. Trans. ASAE 43:867-875.

Wanjura, D.F., J.L. Hatfield, and D.R. Upchurch. 1990. Crop water stress index relationships with crop productivity. Irrig. Sci. 11:93-99.

Wiegand, C.L., A.H. Gerbermann, K.P. Gallo, B.L. Blad, and D. Dusek. 1990. Multisite analyses of spectral-biophysical data for corn. Remote Sens. Environ. 33:1-16.

Wiegand, C.L., and J.L. Hatfield. 1988. The spectral-agronomic multisitemulticrop analyses (SAMMA) project. Int. Arch. Photogramm. Remote Sens. 27(B7):696-706.

Wiegand, C.L., S.J. Maas, J.K. Aase, J.L. Hatfield, P.J. Pinter, Jr., R.D. Jackson, E.T. Kanemasu, and R.L. Lapitan. 1992. Multisite analyses of spectral-biophysical data for wheat. Remote Sens. Environ. 42:1-21.

Wiegand, C.L., and L.N. Namken. 1966. Influences of plant moisture stress, solar radiation, and air temperature on cotton leaf temperature. Agron. J. 58:582-586.

Wiegand, C.L., and A.J. Richardson. 1984. Leaf area, light interception, and yield estimates from spectral component analysis. Agron. J. 76:543-548

Wiegand, C.L., A.J. Richardson, and E.T. Kanemasu. 1979. Leaf-area index estimates for wheat from Landsat and their implication for evapotranspiration and crop modeling. Agron. J. 71:336-342.

Woolley, J.T. 1971. Reflectance and transmittance of light by leaves. Plant Physiol. 47:656-662.

Young, A., and G. Britton. 1990. Carotenoids and stress. p. 87-112. In R.G. Alscher and J.R. Cumming (ed.) Stress responses in plants: Adaptation and acclimation mechanisms. Wiley-Liss, New York.

Yoder, B.J., and R.E. Pettigrew-Crosby. 1995. Predicting nitrogen and chlorophyll concentrations from reflectance spectra $(400-2500 \mathrm{~nm})$ at leaf and canopy scales. Remote Sens. Environ. 53:199-211.

Zhang, L., R. Lemeur, and J.P. Goutorbe. 1995. A one-layer resistance model for estimating regional evapotranspiration using remote sensing data. Agric. For. Meteorol. 77:241-261 